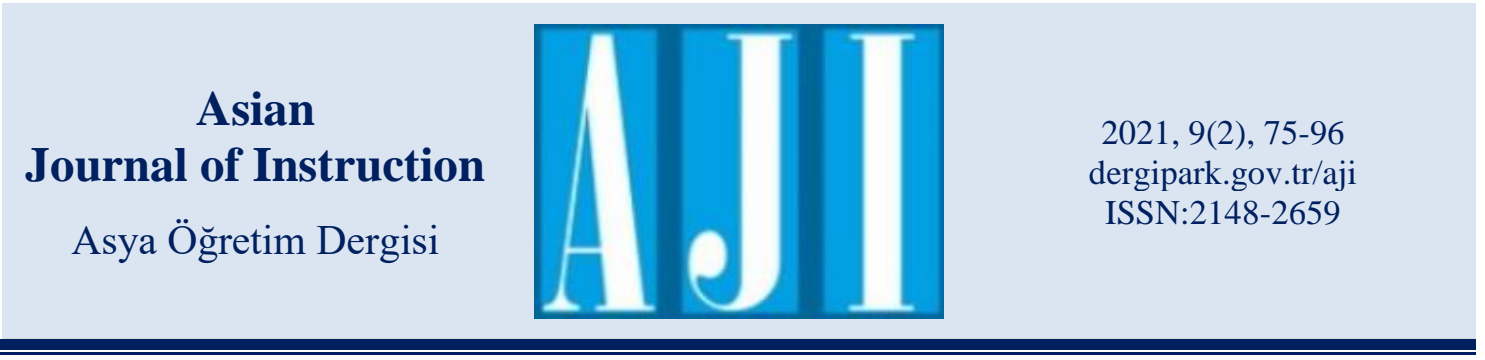

Geliş Tarihi: 23/09/2021

Kabul Tarihi: 16/12/2021

Yayınlanma Tarihi: 31/12/2021

\title{
Ortaokul Matematik Öğretmenlerinin Yansıtıcı Düşünme Eğilimleri ile Yapılandırmacı Öğrenme Ortamı Oluşturma Düzeyleri Arasındaki İlişki* $^{*}$
}

\author{
Aysel Atılkan Tunçer ${ }^{1}$, Ahmet Sapancı ${ }^{2}$
}

Atılkan Tunçer, A., \& Sapanc1, A. (2021). Ortaokul matematik öğretmenlerinin yansıtıcı düşünme eğilimleri ile yapılandırmacı öğrenme ortamı oluşturma düzeyleri arasındaki ilişki. Asian Journal of Instruction, 9(2), 75-96. https://doi.org/10.47215/aji.1000051

\section{$\ddot{O} \mathbf{z}$}

Bu çalışmanın amacı ortaokul matematik öğretmenlerinin yansıtıcı düşünme eğilimleri ile yapılandırmacı öğrenme ortamı oluşturma düzeyleri arasındaki ilişkiyi incelemektir. İlişkisel tarama modeline uygun şekilde gerçekleştirilen çalışmadan elde edilen veriler istatistiksel paket program ile analiz edilmiştir. Araştırma örneklemi Düzce, Karabük, Kastamonu ve Çorum illerinde görev yapan 852 ortaokul matematik öğretmeni arasından uygun örnekleme tekniği ile seçilen 442 katılımcıdan oluşmaktadır. Araştırma kapsamında veri toplama aracı olarak Yansıtıcı Düşünme Eğilim Ölçeği ve Yapılandırmacı Öğrenme Ortamı Ölçeği uygulanmıştır. Verilerin analizinde betimsel istatistiklerden aritmetik ortalama, standart sapma, çarpıklık ve basıklık değerleri ile parametrik testlerden bağımsız gruplar $t$-testi, tek yönlü varyans analizi, Pearson korelasyon analizi ve çoklu doğrusal regresyon analizi kullanılmıştır. Araştırmadan elde edilen sonuçlara göre matematik öğretmenlerinin yansıtıcı düşünme eğilimleri ile yapılandırmacı öğrenme ortamı oluşturma düzeyleri arasında pozitif yönlü orta düzeyde anlamlı ilişki bulunmuştur. Sürekli ve amaçlı düşünme, öngörülü ve içten olma, açık fikirlilik ve araştırmacı eğilimlerinin matematik öğretmenlerin yapılandırmacı öğrenme ortamı oluşturma düzeylerinin anlamlı yordayıcıları olduğu tespit edilmiştir. Yansıtıcı düşünme bağımsız değişkenleri, yapılandırmacı öğrenme ortamı oluşturma düzeyindeki toplam varyansın \%37'sini açılamaktadır.

Anahtar Kelimeler: Ortaokul matematik öğretmenleri, yansıtıcı düşünme eğilimi, yapılandırmacı öğrenme ortamı

\section{The Relationship Between Reflective Thinking Tendencies of Secondary School Mathematics Teachers and The Levels of Creating Constructivist Learning Environment}

\begin{abstract}
The aim of this study is to examine the relationship between the reflective thinking dispositions of secondary school mathematics teachers and their levels of creating a constructivist learning environment. The data obtained from the

\footnotetext{
* Bu çalışma ikinci yazarın danışmanlığında, birinci yazar tarafından, Düzce Üniversitesi Sosyal Bilimler Enstitüsünde hazırlanan “Ortaokul Matematik Öğretmenlerinin Yansıtıcı Düşünme Eğilimleri ile Yapılandırmacı Öğrenme Ortamı Oluşturma Düzeyleri Arasındaki İlişki” başlıklı yüksek lisans tez çalışmasından üretilmiştir.

${ }^{1}$ Bilim uzmanı, Gümüşova 75. Y11 Ortaokulu, https://orcid.org/0000-0002-1319-3679, anatolia1678@ gmail.com

2 Dr. Öğr. Üyesi, Düzce Üniversitesi Eğitim Fakültesi, https://orcid.org/0000-0003-4688-6890, ahmetsapanci@duzce.edu.tr
} 
study, which was carried out by the relational survey model, were analyzed with a statistical package program. The research sample consists of 442 participants selected by convenient sampling technique among 852 secondary school mathematics teachers working in the provinces of Düzce, Karabük, Kastamonu and Çorum. Reflective Thinking Tendency Scale and Constructivist Learning Environment Scale were applied as data collection tools within the scope of the research. In the analysis of the data, mean, standard deviation, skewness and kurtosis values from descriptive statistics and independent groups t-test from parametric tests, one-way analysis of variance, Pearson correlation analysis and multiple linear regression analysis were used. According to the findings obtained from the research, a positive and moderately significant relationship was found between the reflective thinking dispositions of mathematics teachers and their levels of creating a constructivist learning environment. It has been determined that continuous and purposeful thinking, foresight and sincerity, open-mindedness and researcher tendencies are significant predictors of mathematics teachers' levels of creating a constructivist learning environment. Reflective thinking independent variables explain $37 \%$ of the total variance in creating a constructivist learning environment.

Keywords: Constructivist learning environment, reflective thinking disposition, secondary school mathematics teachers

\section{Giriş}

Matematik öğretmenlerin mesleki gelişimleri için önemli bir itici güç olarak kabul edilen yansıtıcı düşünme, matematik eğitimi hedeflerinin gerçekleştirilmesinde, matematik öğretiminin karşılaştığ1 problemlere çözüm üretilmesinde ve matematik sınıflarındaki deneyimlerinin değerlendirilmesinde büyük rol oynamaktadır. Yansitıcı düșünme, öğrencilerin öğrenmelerinin sorumluluğunu üstlenmelerini, hedeflerini tanımlamalarını ve öğrenme süreçlerine verimli katkılarda bulunmalarını sağlar. Bu nedenle öğretmenlerin, öğrencilerin yansıtıcı düşünme becerilerini geliştirmeleri önemlidir. Ancak yansitıcı düşünmenin öğrencilere kazandırılması için öncelikle öğrencilerin bu özelliklere sahip olması gerekmektedir. $\mathrm{Bu}$ nedenle yansitıcı düşünme, öğretmen eğitiminin ve eğitim programlarının önemli bir parçası olarak düşünülmelidir (Aldahmash, Alshalhoub \& Naji, 2021).

Yansıtıcı düşünme kavramının temellerinin çok eskiye dayandığı söylenebilir (Gürbüz \& Bozan, 2018). Çalışmanın temeline inildiğinde yansıtıcı düşünmenin ilk tanımlamalarının Dewey (1993) tarafından yapıldığ 1 daha sonra ise üzerinde birçok çalışmanın bulunduğu görülmektedir (Deringöl, 2019; Köksal \& Demirel, 2008; Ocak, Ocak, \& Saban, 2013; Yumuşak, 2015). Daha sonraki araştırma süreçlerinde bu tanımlamayı geliştirerek yansıtıcı düşünmeye farklı bakış açıları sunulmuştur. Literatürde ifade edilen yansitıcı düşünme olumlu ve olumsuz durumların tespit edilmesi ve bunun neticesinde saptanan problemlerin çözülmesine yönelik düşünme biçimi olarak ifade edilmektedir (Saygılı \& Atahan, 2014). Yansıtıcı düşünce kavramı kendi içerisinde yansıtma kavramını barındırmaktadır. Yansıtma, kişinin bir konu hakkında fikirlerini ifade etmesi, tutumlarını ve becerilerini gösterebilmesidir (Duban \& Yelken, 2010).

Mezirow'a (1991) göre, yansıtıcı düşünmenin içeriğini, problem çözme aşaması veya içerik ile ilgili sayıltılara yönelik eleştiriler oluşturmaktadır. $\mathrm{Bu}$ görüşe göre, dayanakların ve varsayımların eleştirilmesi öncelikle problemlerin ortaya konulması ile ilgili olup problemin çözümünde farklılık ortaya çıkmaktadır. Mezirow'a (1991) göre, alışkanlığa dönüşmüş eylemler, düşünmeden gerçekleştirilebilen eylemler ve kendini merkeze alan eylemler, yansitıcı olmayan davranışların üç özelliğidir ve bu özellikler üzerinden değerlendirme yapılarak yansitıcı olan ve olmayan davranışların ayırt edilebilmesi mümkündür.

Eğitim sisteminin temelinde hem eğiticiler hem de eğitim görenler açısından düşünme ve düşünceyi aktarma fikri yatmaktadır. Hatta diğer bütün eğitim bilimlerinin temelinde bu felsefe bulunmaktadır (Deringöl, 2019: 619). İnsanlar varoluşundan bu yana çeşitli gereksinimlerini karşılamak amacı ile bir araya gelmektedir. Eğitim de insanlığın geçmişten bugüne önemli bir ihtiyacıdır. Bu ihtiyacın karşılanabilmesi için de devletler nitelikli eğitim sistemleri oluşturmayı amaçlamaktadır (Güzel, Karataş \& Çetinkaya, 2010). Nitelikli eğitim kavramı hem Türkiye'de 
hem de dünyada yıllardır üzerinde tartışılan bir konudur. Türkiye'de öğretmenlerin niteliklerinin artırılması her zaman önemli konu başlıklarından biri olmuştur (Aydın \& Çelik, 2013). Öğretmen ve öğretmen adaylarından beklenen ise daima kendilerini geliştirmeleri sorumluluklarının farkında olmaları ve kendilerini sorgulayabilmeleri olmuştur (Gözel \& Toptaş, 2017). Nitelikli öğretmenlerin yetiştireceği öğrencilerin hem topluma hem de kendinden sonraki nesillere olan etkisi tartışmasızdır.

Yapılandırmacı eğitim sisteminde öğretmen ve öğretmen adaylarının yeterliliğinde ön şart olarak yansitıcı düşünme becerisinin edinilmiş olması beklenmektedir (Ocak vd., 2013). Yansıtıcı düşünme ile yapılandırmacı yaklaşım kavramları esasen birbirlerini tamamlayan iki kavram olarak karşımıza çıkmaktadır. Bir başka açıdan bakıldığında ise yapılandırmacı yaklaşımın içeriğinde eleştirel bir bakış açısı sonucunda yansıtıcı düşünme becerisinin varlığ 1 görülmektedir (Lale, 2016). Yapılandırmacı yaklaşımda eğitim sisteminde beklenen sonuçlar, özellikle öğrencinin klasik biçimde geçmişten bugüne gelmiş ve kalıplaşmış öğretim modellerinden sıyrılmasıdır. Yansıtıcı düşünce öğrencilerin bilgilerinin yapılandırılması neticesinde eğitim sürecinin öğrenci açısından da eğlenceli hale gelmesini sağlamaktadır (Temel, 2017). Bunun sonucunda ise ezberlenen bilginin yerini öğrenilen bilgi almakta ve böylelikle kazanımlar yaşam boyu kalıcı hale gelmektedir. Bu bakımdan öğrenci yapılandırmacı yaklaşımda öğrenim sürecine hem daha aktif katılım sağlamakta hem de öğrenilen kavramlar ezberlenmek yerine temelinde yatan düşünce açığa çıkarılmaktadır. Yansıtıcı düşünme becerisi de öğrencinin yapılandırmacı eğitim modelinde istenilen sonuçlara ulaşılabilmesi için sahip olunmas1 gereken bir beceridir.

2005 yılından itibaren Türkiye'de uygulanmaya başlanan yapılandırmacı yaklaşımın uygulamaya aktarılmasında yansıtıcı düşünmeye dayalı uygulamalar önemlidir. Yapılandırmacılık ve yansıtıcı uygulama, bilgi ve öğrenmeyle ilgili temel varsayımları paylaşır. Her ikisinin de merkezinde, düşüncenin ve uygulamanın, öğrenme sürecinin ayrılmaz ve temel yönleri olduğu fikri vardır. Bu ilkelerin mesleki gelişim ortamında uygulanması, teori ve uygulama arasındaki yapay sınırları azaltır, her ikisini de sinıfa getirir ve teorinin pratikle bütünleşmesini kolaylaştırır (Osterman, 1999).

$\mathrm{Bu}$ çalışma kapsamında ulaşılabilen araştırmalar incelendiğinde yansıtıcı düşünme ile ilgili araştırmaların çoğunlukla öğretmen ve öğretmen adayları üzerinde yoğunlaştığ 1 , yansıtıcı düşünme becerilerini ölçme ve bu becerileri geliştirici yöntem ve tekniklerin uygulanması ve değerlendirilmesi üzerine araştırmaların olduğu görülmüştür (Agustan, Juniati \& Siswono 2016; Aykar, 2019; Ergüven, 2011; Hasırcı \& Sadık, 2011; Korumaz \& Kılıç, 2015; Norton,1997; Langer, 2002; Lee, 2007; Özden, 2012; Soodmand \& Farahani, 2018; Thahir, Komarudin, Hasanah \& Rahmahwaty, 2019; Töman \& Çimer, 2017; Warden, 2004). Ortaokul matematik öğretmenlerinin yansıtıcı düşünme eğilimleri ile yapılandırmacı öğrenme ortamı oluşturma düzeyleri arasındaki ilişkiyi inceleyen bir çalışmaya rastlanmamıştır. Bu bağlamda, bu çalışma ile ortaokul matematik öğretmenlerinin yansıtıcı düşünme eğilim düzeyleri ile yapılandırmacı öğrenme ortamı oluşturma düzeyleri arasındaki ilişkilerin belirlenmesi amaçlanmıştır. Çalışma sonucunda elde edilen sonuçların gerek ilgili literatüre gerekse öğretmenlerin hizmet öncesi ve hizmet içi eğitim süreçlerinin düzenlenmesinde ihtiyaç analizi çalışmalarına ve uygulama alanında öğretmenlere katkı sağlayacağı düşünülmektedir. Araştırmanın temel amacı kapsamında şu sorulara yanıt aranmıştır:

1. Ortaokul matematik öğretmenlerinin yansıtıcı düşünme eğilimleri ne düzeydedir?

2. Ortaokul matematik öğretmenlerinin yansıtıcı düşünme eğilimleri cinsiyete, kıdeme ve yansıtıcı düşünme ile ilgili eğitim alıp almama durumuna göre farklılaşmakta mıdır? 
3. Ortaokul matematik öğretmenlerinin yapılandırmacı öğrenme ortamı oluşturmaları hangi düzeydedir?

4. Ortaokul matematik öğretmenlerinin yapılandırmacı öğrenme ortamı oluşturma düzeyleri cinsiyete ve kıdeme göre farklılaşmakta mıdır?

5. Ortaokul matematik öğretmenlerinin yansıtıcı düşünme eğilimleri ile yapılandırmacı öğrenme ortamı oluşturma düzeyleri arasında ilişki var mıdır?

6. Ortaokul matematik öğretmenlerinin yansıtıcı düşünme eğilimi düzeylerinin yapılandırmacı öğrenme ortamı oluşturma düzeyini yordama gücü nedir?

\section{Yöntem}

\subsection{Araştırma Modeli}

$\mathrm{Bu}$ araştırmada ortaokul matematik öğretmenlerinin yansıtıcı düşünme eğilimleri ile yapılandırmacı öğrenme ortamı oluşturma düzeyleri arasındaki ilişkiyi incelemek amacıyla nicel araştırma yöntemlerinden, ilişkisel tarama modeli kullanılmıştır. İlişkisel tarama modeli, iki ya da daha fazla değişken arasındaki ilişkinin yönünü ve gücünü belirlemek amacıyla kullanılmaktadır (Karasar, 2012).

\subsection{Evren ve Örneklem}

Araştırma evrenini, Düzce, Karabük, Çorum ve Kastamonu illerinde görev yapan toplam 852 ortaokul matematik öğretmeni, örneklemi ise uygun (kolayda) örneklem tekniği ile seçilen 442 ortaokul matematik öğretmeni oluşturmaktadır. Araştırma örneklemine ilişkin bilgiler Tablo 1 'de verilmiştir.

Tablo 1. Örneklemin Cinsiyet, Kıdem ve Eğitim Alma Değişkenlerine Göre Dağılımı

\begin{tabular}{llll}
\hline \multicolumn{2}{c}{ Değişkenler } & $\mathbf{N}$ & \% \\
\hline \multirow{2}{*}{ Cinsiyet } & Kadın & 242 & 54.8 \\
\cline { 2 - 4 } & Erkek & 200 & 45.2 \\
\hline \multirow{4}{*}{ Kidem } & $1-5$ yıl & 106 & 24 \\
\cline { 2 - 4 } & $6-10$ yıl & 147 & 33.3 \\
\cline { 2 - 4 } & $11-15$ yıl & 112 & 25.3 \\
\cline { 2 - 4 } & 16 yll ve üstü & 77 & 17.4 \\
\hline Yansitıcı Düşünme ile İlgili & Evet & 432 & 2.3 \\
\cline { 2 - 4 } Ĕgitim Alma Durumu & Hayır & 442 & 100 \\
\hline Toplam & & & \\
\hline
\end{tabular}

\subsection{Veri Toplama Araçları}

Çalışmada veri toplama aracı olarak Kişisel Bilgi Formu, Yansıtıcı Düşünme Eğilim Ölçeği ve Yapılandırmacı Öğrenme Ortamı Oluşturma Ölçeği kullanılmıştır.

\subsubsection{Kişisel Bilgi Formu}

Araştırmacı tarafindan geliştirilen kişisel bilgi formu, cinsiyet, kıdem, mesleği seçme durumu ve yansıtıcı düşünme ile ilgili eğitim alıp almama ile ilgili bilgiler içermektedir.

\subsubsection{Yansıttcı Düşünme Ĕğilim Ölçeği (YANDE)}

YANDE, öğretmen ve öğretmen adaylarının yansıtıcı düşünme eğilimlerinin düzeylerini belirlemek amacı ile Semerci (2007) tarafından geliştirilmiştir. Ölçek, 20'si olumsuz, 15'i olumlu toplam 35 maddeden oluşmaktadır. Olumsuz maddeler tersten puanlanmıştır $(1=5,2=4$, 
3=3, 4=2, 5=1). Ölçek 5'li likert tipinde hazırlanmış olup maddelere verilen yanıtlar "Hiç Katılmıyorum (1)", "Çoğunlukla Katılmıyorum (2)", "Kısmen Katılıyorum (3)", "Çoğunlukla Katılıyorum (4)" ve "Tamamen Katılıyorum (5)" şeklinde sunulmuştur. Ölçeğin Cronbach alfa güvenirlik katsayıları ölçeğin toplamı için .88 olarak bulunmuştur. Cronbach alfa güvenirlik katsayısı 29 olarak bulunan "mesleğe bakış" alt boyutu veri analizinden çıkarılmıştır. Diğer alt boyutların güvenirlik katsayısı .71 ile .74 arasında bulunmuştur.

\subsubsection{Yapılandırmacı Öğrenme Ortamı Ölçeği}

Öğretmenlerin yapılandırmacı öğrenme ortamı oluşturma düzeylerini belirlemek için Tenenbaum, Naidu, Jegede \& Austin (2001) tarafından geliştirilen Yapılandırmacı Öğrenme Ortamı Ölçeği'nin Fer ve Cırık (2006) tarafından Türkçe uyarlaması gerçekleştirilmiştir. Ölçek yedi alt boyuttan ve 30 maddeden oluşmaktadır. Ölçekte olumsuz madde bulunmamaktadır.. 5'li likert tipi ölçeğe göre hazırlanmış olup maddelere verilen yanıtlar "Hiç Katılmıyorum (1)", "Çoğunlukla Katılmıyorum (2)", "Kısmen Katılıyorum (3)", "Çoğunlukla Katılıyorum (4)" ve "Tamamen Katılıyorum (5)" şeklinde sunulmuştur. Ölçeğin Cronbach alfa güvenirlik katsayıları ölçeğin toplamı için .94 olarak bulunmuştur. Alt boyutların güvenirlik katsayıları .74 ile .93 arasindadır.

\subsection{Verilerin Analizi}

Araştırma sonucunda elde edilen verilerin analizi istatistiksel paket programı aracılığıyla yapılmıştır. Elde edilen bulgular \%95 güven aralığ $\%$ \%5 anlamlılık düzeyinde değerlendirilmiştir. Verilerin analizi için uygun istatistiksel tekniklerin seçilebilmesi için öncelikle normallik, doğrusallık, varyansların homojenliği gibi önkoşullar incelenmiş ve herhangi bir ihlalin yapılmadığı belirlenmiştir. Katılımcıların yansıtıcı düşünme eğilim ve yapılandırmacı öğrenme ortamı oluşturma düzeylerinin belirlenmesinde frekans, aritmetik ortalama ve standart sapma kullanılmıştır. Gruplar arasındaki farklılıkların belirlenmesinde bağımsız gruplar $t$-testi ve tek yönlü ANOVA kullanılmıştır. ANOVA'da gruplar arası farkın kaynağını belirlerken varyanslar homojen dağıldığı için Post-Hoc Scheffe Testi kullanılmıştır. Değişkenler arası ilişki analizlerinde ise Pearson korelasyonu ve çoklu doğrusal regresyon kullanılmıştır.

\subsection{Etik Kurul İzni}

Yapılan bu çalışmada "Yükseköğretim Kurumları Bilimsel Araştırma ve Yayın Etiği Yönergesi" kapsamında uyulması belirtilen tüm kurallara uyulmuştur. Bu çalışma için etik kurul izni Düzce Üniversitesi Bilimsel Araştırma ve Yayın Etik Kurulu'nun 20/06/2019 tarihli ve 2019/58 numaralı kararı ile alınmıştır.

\section{Bulgular}

\section{1. Öğretmenlerin Yansıtıcı Düşünme Eğilimlerine İlişkin Bulgular}

Ortaokul matematik öğretmenlerinin yansıtıcı düşünme eğilim düzeylerine ait bulgular Tablo 2'de verilmiştir. 
Tablo 2. Ortaokul Matematik Öğretmenlerinin Yansıtıcı Düşünme Eğilim Düzeylerinin Alt Boyutlarına Ait Betimsel İstatistikleri

\begin{tabular}{lccccc}
\hline \multicolumn{1}{c}{ Alt Boyutlar } & N & Min & Max & $\overline{\mathbf{X}}$ & Ss \\
\hline Sürekli ve Amaçlı Düşünme & 442 & 3.29 & 5.00 & 4.42 & .39 \\
\hline Açık Fikirlilik & 442 & 2.83 & 5.00 & 4.58 & .48 \\
\hline Sorgulayıcı ve Etkili Öğretim & 442 & 2.80 & 5.00 & 4.52 & .51 \\
\hline Öğgretim Sorumluluğu ve Bilimsellik & 442 & 3.20 & 5.00 & 4.56 & .37 \\
\hline Araştırmacı & 442 & 2.00 & 5.00 & 4.29 & .51 \\
\hline Öngörülü ve İçten Olma & 442 & 2.00 & 5.00 & 4.22 & .59 \\
\hline Yansıtıcı Eğilim & 442 & 3.55 & 5.00 & 4.44 & .33 \\
\hline
\end{tabular}

Tablo 2'den elde edilen bulgulara göre öğretmenlerinin yansıtıcı düşünme eğilim ölçeğinden aldıkları puan ortalamaları ölçeğin toplamı için $(\overline{\mathrm{X}}=4.44)$ olarak belirlenmiştir. Buna göre öğretmenlerin yansıtıcı düşünme eğilimlerinin çok yüksek düzeyde olduğu söylenebilir. Alt boyut puan ortalamalarına bakıldığında öğretmenlerin yansıtıcı düşünme eğilimlerinin çok yüksek olduğu görülmektedir.

\section{2. Öğretmenlerin Yansıtıcı Düşünme Eğilimlerinin Cinsiyet, Kıdem ve Eğitim Alma Değişkenlerine Ait Bulguları}

Öğretmenlerin yansitıcı düşünme eğilimlerinin cinsiyet değişkenine göre farklılaşma durumlarını incelemek için yapılan bağımsız gruplar $t$-testi sonuçları Tablo 3 'te verilmiştir.

Tablo 3. Ortaokul Matematik Öğretmenlerinin Yansıtıcı Düşünme Eğilimlerinin Cinsiyete Göre Bağımsız Gruplar $t$-testi Sonuçları

\begin{tabular}{|c|c|c|c|c|c|c|c|}
\hline Alt Boyutlar & Cinsiyet & $\mathbf{N}$ & $\overline{\mathbf{X}}$ & Ss & $t$ & Sd & $p$ \\
\hline \multirow{2}{*}{ Sürekli ve Amaçlı Düşünme } & Kadın & 242 & 4.40 & .39 & \multirow{2}{*}{-1.11} & \multirow{2}{*}{440} & \multirow{2}{*}{.267} \\
\hline & Erkek & 200 & 4.44 & .40 & & & \\
\hline \multirow{2}{*}{ Açık Fikirlilik } & Kadın & 242 & 4.63 & .46 & \multirow{2}{*}{2.09} & \multirow{2}{*}{440} & \multirow{2}{*}{.037} \\
\hline & Erkek & 200 & 4.53 & .50 & & & \\
\hline \multirow{2}{*}{ Sorgulayıcı ve Etkili Öğretim } & Kadın & 242 & 4.56 & .49 & \multirow{2}{*}{1.49} & \multirow{2}{*}{440} & \multirow{2}{*}{.136} \\
\hline & Erkek & 200 & 4.48 & .53 & & & \\
\hline \multirow{2}{*}{$\begin{array}{l}\text { Öğretim Sorumluluğu ve } \\
\text { Bilimsellik }\end{array}$} & Kadın & 242 & 4.58 & .36 & \multirow{2}{*}{.92} & \multirow{2}{*}{440} & \multirow{2}{*}{.355} \\
\hline & Erkek & 200 & 4.54 & .37 & & & \\
\hline \multirow{2}{*}{ Araştırmacı } & Kadın & 242 & 4.32 & .46 & \multirow{2}{*}{1.51} & \multirow{2}{*}{388.92} & \multirow{2}{*}{.131} \\
\hline & Erkek & 200 & 4.24 & .55 & & & \\
\hline \multirow{2}{*}{ Öngörülü ve İçten Olma } & Kadın & 242 & 4.25 & .58 & \multirow{2}{*}{1.04} & \multirow{2}{*}{440} & \multirow{2}{*}{.296} \\
\hline & Erkek & 200 & 4.19 & .61 & & & \\
\hline \multirow{2}{*}{ Yansıtıcı Eğilim } & Kadın & 242 & 4.46 & .31 & \multirow{2}{*}{1.42} & \multirow{2}{*}{409.25} & \multirow{2}{*}{.154} \\
\hline & Erkek & 200 & 4.41 & .34 & & & \\
\hline
\end{tabular}

Tablo 3 incelendiğinde öğretmenlerin yansıtıcı düşünme eğilimlerinde cinsiyete göre ölçek toplam puanı için anlamlı farklılık olmadığı bulunmuştur $\left(\mathrm{t}_{(409.25)}=1.42, p>.05\right)$. Kadın ve erkek öğretmenlerin yansitıcı düşünme eğilimlerinin birbirine yakın olduğu görülmektedir. Açık fikirlilik alt boyutunda ise gruplar arasında istatistiksel olarak anlamlı farklılık olduğu $\left(\mathrm{t}_{(440)}=2.09, p<.05\right)$, kadın öğretmenlerin açık fikirlilik ortalamalarının erkeklerden yüksek olduğu görülmektedir. Ancak hesaplanan etki büyüklüğü (Cohen $d=.19$ ) bu farkın düşük düzeyde olduğunu göstermektedir.

Öğretmenlerin yansıtıcı düşünme eğilimlerinin kıdem değişkenine göre farklılaşma durumlarını incelemek için yapılan tek yönlü ANOVA sonuçları Tablo 4'te verilmiştir. 
Ortaokul Matematik Öğretmenlerinin Yansıtıcı Düşünme Eğilimleri ile Yapılandırmacı Öğrenme Ortamı Oluşturma Düzeyleri Arasındaki İlişsi

Tablo 4. Ortaokul Matematik Öğretmenlerinin Yansıtıcı Düşünme Eğilimlerinin Kıdem Değişkenine Göre Tek Yönlü ANOVA Sonuçları

\begin{tabular}{|c|c|c|c|c|c|c|c|c|c|}
\hline Alt Boyutlar & Kıdem & $\mathbf{N}$ & $\overline{\mathbf{X}}$ & Ss & Sd & $\mathbf{F}$ & $p$ & Fark & $\eta^{2}$ \\
\hline \multirow{4}{*}{$\begin{array}{l}\text { Sürekli ve Amaçlı } \\
\text { Düşünme }\end{array}$} & 1. $1-5 \mathrm{y} 1 \mathrm{l}$ & 106 & 4.38 & .42 & \multirow{4}{*}{3} & \multirow{4}{*}{4.09} & \multirow{4}{*}{.007} & \multirow{4}{*}{$4-2$} & \multirow{4}{*}{.02} \\
\hline & 2. $6-10 \mathrm{y} 1 \mathrm{l}$ & 147 & 4.36 & .37 & & & & & \\
\hline & 3. $11-15 \mathrm{y} 1 \mathrm{l}$ & 112 & 4.46 & .38 & & & & & \\
\hline & 4. $16 \mathrm{y} 1 \mathrm{l}$ ve üstü & 77 & 4.56 & .38 & & & & & \\
\hline \multirow{4}{*}{ Açık Fikirlilik } & 1. $1-5 \mathrm{y} 11$ & 106 & 4.58 & .47 & \multirow{4}{*}{3} & \multirow{4}{*}{.44} & \multirow{4}{*}{.720} & & \\
\hline & 2. $6-10 \mathrm{y} 1 \mathrm{l}$ & 147 & 4.60 & .49 & & & & & \\
\hline & 3. $11-15$ y1l & 112 & 4.54 & .49 & & & & & \\
\hline & 4. 16 yıl ve üstü & 77 & 4.61 & .46 & & & & & \\
\hline \multirow{4}{*}{$\begin{array}{l}\text { Sorgulayıcı ve Etkili } \\
\text { Öğretim }\end{array}$} & 1. $1-5 \mathrm{y} 1 \mathrm{l}$ & 106 & 4.49 & .55 & \multirow{4}{*}{3} & \multirow{4}{*}{3.54} & \multirow{4}{*}{.015} & \multirow{4}{*}{$4-2$} & \multirow{4}{*}{.02} \\
\hline & 2. $6-10 \mathrm{y} 1 \mathrm{l}$ & 147 & 4.46 & .56 & & & & & \\
\hline & 3. $11-15 \mathrm{y} 1 \mathrm{l}$ & 112 & 4.52 & .44 & & & & & \\
\hline & 4. $16 \mathrm{yll} \mathrm{ve} \mathrm{üstü}$ & 77 & 4.69 & .39 & & & & & \\
\hline \multirow{4}{*}{$\begin{array}{l}\text { Öğretim } \\
\text { Sorumluluğu ve } \\
\text { Bilimsellik }\end{array}$} & 1. $1-5 \mathrm{y} 11$ & 106 & 4.52 & .36 & \multirow{4}{*}{3} & \multirow{4}{*}{2.44} & \multirow{4}{*}{.064} & & \\
\hline & 2. $6-10 \mathrm{y} 1 \mathrm{l}$ & 147 & 4.54 & .39 & & & & & \\
\hline & 3. $11-15 \mathrm{y} 1 \mathrm{l}$ & 112 & 4.57 & .38 & & & & & \\
\hline & 4. 16 yıl ve üstü & 77 & 4.65 & .31 & & & & & \\
\hline \multirow{4}{*}{ Araştırmacı } & 1. $1-5 \mathrm{y} 1 \mathrm{l}$ & 106 & 4.23 & .50 & \multirow{4}{*}{3} & \multirow{4}{*}{5.49} & \multirow{4}{*}{.001 } & & \multirow{4}{*}{.03} \\
\hline & 2. $6-10 \mathrm{y} 1 \mathrm{l}$ & 147 & 4.21 & .53 & & & & $4-1$ & \\
\hline & 3. $11-15 \mathrm{y} 1 \mathrm{l}$ & 112 & 4.30 & .46 & & & & $4-2$ & \\
\hline & 4. $16 \mathrm{yll} \mathrm{ve} \mathrm{üstü}$ & 77 & 4.48 & .51 & & & & & \\
\hline \multirow{4}{*}{$\begin{array}{l}\text { Öngörülü ve İçten } \\
\text { Olma }\end{array}$} & 1. $1-5 \mathrm{y} 1 \mathrm{l}$ & 106 & 4.07 & .66 & \multirow{4}{*}{3} & \multirow{4}{*}{9.83} & \multirow{4}{*}{.000} & $3-1$ & \multirow{4}{*}{.06} \\
\hline & 2. $6-10 \mathrm{y} 1 \mathrm{l}$ & 147 & 4.11 & .53 & & & & $3-2$ & \\
\hline & 3. $11-15$ y1l & 112 & 4.39 & .55 & & & & $4-1$ & \\
\hline & 4. 16 yıl ve üstü & 77 & 4.41 & .58 & & & & $4-2$ & \\
\hline & 1. $1-5 \mathrm{y} 1 \mathrm{l}$ & 106 & 4.39 & .35 & & & & & \\
\hline Yancitı́ Ĕ̆ilim & 2. $6-10 \mathrm{y} 1 \mathrm{l}$ & 147 & 4.39 & .32 & 3 & 612 & 000 & $4-1$ & 04 \\
\hline 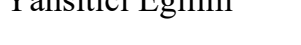 & 3. $11-15$ y1l & 112 & 4.46 & .31 & 3 & 0.12 & .000 & $4-2$ & .04 \\
\hline & 4. 16 y1l ve üstü & 77 & 4.57 & .29 & & & & & \\
\hline
\end{tabular}

Tablo 4 incelendiğinde öğretmenlerin yansıtıcı düşünme eğilim düzeylerinde kıdeme göre ölçek toplam puanı için anlamlı farklılık görülmektedir $\left(\mathrm{F}_{(3,438)}=6.12, p<.05\right)$. Elde edilen etki büyüklüğ̈̈ $\left(\eta^{2}=.04\right)$ bu farkın düşük düzeyde olduğunu göstermektedir. Ayrıca sürekli ve amaçlı düşünme $\left(\mathrm{F}_{(3,438)}=4.09, p<.05\right)$, sorgulayıc1 ve etkili öğretim $\left(\mathrm{F}_{(3,438)}=3.54, p<.05\right)$, araştırmac1 $\left(\mathrm{F}_{(3,438)}=5.49, p<.05\right)$ ve öngörülü ve içten olma $\left(\mathrm{F}_{(3,438)}=9.83, p<.05\right)$ alt boyutlarında ortalama puanlarında anlamlı farklılık tespit edilmiştir. Elde edilen etki büyüklüklerine göre bu farkların düşük ve orta düzeyde oldukları görülmektedir. Diğer alt boyutlarda anlamlı bir farklılık olmadığ 1 bulunmuştur.

Elde edilen anlamlı farklılıkların kaynağını belirlemek için Scheffe testi yapılmıştır. Yapılan Scheffe testi sonucuna göre sürekli ve amaçlı düşünme alt boyutunda 16 yıl ve üstü kıdeme sahip olan matematik öğretmenlerinin $(\bar{X}=4.54), 6-10$ yıl kıdeme sahip olan matematik öğretmenlerinden $(\overline{\mathrm{X}}=4.36)$ daha yüksek yansıtıcı düşünme eğiliminde oldukları görülmektedir. Sorgulayıc1 ve etkili öğretim alt boyutunda 16 yıl ve üstü kıdeme sahip olan öğretmenler $(\overline{\mathrm{X}}=$ 4.69), 6-10 yıl kıdeme sahip olan öğretmenlerden $(\bar{X}=4.46)$ daha yüksek yansıtıcı düşünme eğilimine sahiptirler. Araştırmacı alt boyutunda 16 yıl ve üstü kıdeme sahip olan öğretmenler $(\bar{X}=4.48), 1-5$ yıl kıdeme sahip olan öğretmenlerden $(\bar{X}=4.23)$ ve 6-10 y1l kıdeme sahip olan öğretmenlerden $(\bar{X}=4.21)$ daha yüksek yansıtıcı düşünme eğilimine sahiptir. Öngörülü ve içten olma alt boyutunda 11-15 yıl kıdeme sahip olan öğretmenler $(\bar{X}=4.39)$ ile 16 yıl ve üstü kıdeme sahip olan öğretmenlerin $(\overline{\mathrm{X}}=4.41), 1-5$ yıl kıdeme sahip olan öğretmenlerden $(\overline{\mathrm{X}}=4.07)$ ve 6-10 
y1l kıdeme sahip olan öğretmenlerden $(\bar{X}=4.11)$ daha yüksek yansıtıcı düşünme eğilimine sahip oldukları görülmektedir. Elde edilen bulgular incelendiğinde ortaokul matematik öğretmenlerinin yansıtıcı düşünme eğilim ölçeği toplam puanı için 16 yıl ve üstü kıdeme sahip olan öğretmenlerin $(\overline{\mathrm{X}}=4.57), 1-5$ y1l kıdeme sahip olan öğretmenlerden $(\overline{\mathrm{X}}=4.39)$ ve 6-10 y1l kıdeme sahip olan öğretmenlerden $(\bar{X}=4.39)$ daha yüksek yansıtıcı düşünme eğilimine sahip oldukları görülmektedir.

Öğretmenlerin yansıtıcı düşünme eğilimlerinin, yansıtıcı düşünme ile ilgili eğitim alma durumlarına göre anlamlı farklılaşma durumlarını belirlemek için yapılan bağımsız gruplar $t$ testi sonuçları Tablo 5 'te verilmiştir.

Tablo 5. Ortaokul Matematik Öğretmenlerinin Yansıtıcı Düşünme Eğilimlerinin Hizmet İçi Eğitim Alıp Almama Durumlarına Göre Bağımsız Gruplar $t$-testi Sonuçları

\begin{tabular}{|c|c|c|c|c|c|c|c|}
\hline Alt Boyutlar & Hizmet İçi Eğitim & $\mathbf{N}$ & $\overline{\mathbf{X}}$ & Ss & $t$ & Sd & $p$ \\
\hline \multirow{2}{*}{$\begin{array}{l}\text { Sürekli ve Amaçlı } \\
\text { Düşünme }\end{array}$} & Evet & 10 & 4.34 & .50 & \multirow{2}{*}{-.65} & \multirow{2}{*}{440} & \multirow{2}{*}{.512} \\
\hline & Hayır & 432 & 4.42 & .39 & & & \\
\hline \multirow{2}{*}{ Açık Fikirlilik } & Evet & 10 & 4.70 & .42 & \multirow{2}{*}{.73} & \multirow{2}{*}{440} & \multirow{2}{*}{.463} \\
\hline & Hayır & 432 & 4.58 & .48 & & & \\
\hline \multirow{2}{*}{$\begin{array}{l}\text { Sorgulayıcı ve Etkili } \\
\text { Öğretim }\end{array}$} & Evet & 10 & 4.52 & .47 & \multirow[b]{2}{*}{-.04} & \multirow[b]{2}{*}{440} & \multirow[b]{2}{*}{.965} \\
\hline & Hayır & 432 & 4.52 & .51 & & & \\
\hline \multirow{2}{*}{$\begin{array}{l}\text { Öğretim Sorumluluğu ve } \\
\text { Bilimsellik }\end{array}$} & Evet & 10 & 4.34 & .51 & \multirow{2}{*}{-1.94} & \multirow{2}{*}{440} & \multirow{2}{*}{.052} \\
\hline & Hayır & 432 & 4.57 & .36 & & & \\
\hline \multirow{2}{*}{ Araştırmacı } & Evet & 10 & 4.33 & .47 & \multirow{2}{*}{.26} & \multirow{2}{*}{440} & \multirow{2}{*}{.789} \\
\hline & Hayır & 432 & 4.28 & .51 & & & \\
\hline \multirow{2}{*}{ Öngörülü ve İçten Olma } & Evet & 10 & 4.25 & .57 & \multirow{2}{*}{.11} & \multirow{2}{*}{440} & \multirow{2}{*}{911} \\
\hline & Hayır & 432 & 4.22 & .60 & & & \\
\hline \multirow{2}{*}{ Yansitıc1 Eğilim } & Evet & 10 & 4.42 & .42 & \multirow{2}{*}{-.21} & \multirow{2}{*}{440} & \multirow{2}{*}{.832} \\
\hline & Hayır & 432 & 4.44 & .33 & & & \\
\hline
\end{tabular}

Tablo 5 incelendiğinde öğretmenlerin yansıtıcı düşünme eğilimlerinde yansıtıcı düşünme ile ilgili hizmet içi eğitim alma durumlarına göre ölçek toplam puanı için anlamlı farklılık görülmemektedir $\left(\mathrm{t}_{(440)}=-.21, \mathrm{p}>.05\right)$. Buna göre yansıtıcı düşünme ile ilgili eğitim almanın öğretmenlerin yansıtıcı düşünme eğilimleri üzerinde anlamlı bir etkisinin olmadığı söylenebilir. Diğer taraftan tüm alt boyutlarda da anlamlı farklılık görülmemektedir.

\section{3. Öğretmenlerin Yapılandırmacı Öğrenme Ortamı Oluşturma Düzeylerine İlişsin Bulgular}

Ortaokul matematik öğretmenlerinin yapılandırmacı öğrenme ortamı oluşturma düzeylerine ait bulgular Tablo 6'da verilmiştir.

Tablo 6. Ortaokul Matematik Öğretmenlerinin Yapılandırmacı Öğrenme Ortamı Oluşturma Düzeylerinin Alt Boyutlarına Ait Betimsel İstatistikleri

\begin{tabular}{lccccc}
\hline \multicolumn{1}{c}{ Alt Boyutlar } & $\mathbf{N}$ & Min & Max & $\overline{\mathbf{X}}$ & Ss \\
\hline Tartışma ve Görüşmeler & 442 & 1.80 & 5.00 & 4.04 & .69 \\
Kavramsal Çelişkiler & 442 & 1.00 & 5.00 & 3.14 & 1.41 \\
Düşünceleri Diğerleriyle Paylaşma & 442 & 1.50 & 5.00 & 3.93 & .71 \\
Materyal ve Kaynakların Çözüme Götürmesi & 442 & 1.67 & 5.00 & 3.86 & .75 \\
Kavram Keşfi ve Yansıtma İçin Motive Etme & 442 & 1.50 & 5.00 & 3.97 & .75 \\
Öğrenen İhtiyaçlarını Karşlama & 442 & 1.40 & 5.00 & 3.91 & .72 \\
Anlam Oluşturma ve Gerçek Yaşamla Bağlantı & 442 & 1.50 & 5.00 & 4.12 & .69 \\
Yapılandırmacı Öğrenme Ortamı & 442 & 1.53 & 5.00 & 3.89 & .57 \\
\hline
\end{tabular}


Ortaokul Matematik Öğretmenlerinin Yansıtıcı Düşünme Eğilimleri ile Yapılandırmacı Öğrenme Ortamı Oluşturma Düzeyleri Arasındaki İlişki

Tablo 6'dan elde edilen bulgulara göre öğretmenlerinin yapılandırmacı öğrenme ortam1 ölçeğinden aldıkları puan ortalamalarının ölçeğin toplamı için $(\overline{\mathrm{X}}=3.89)$ olarak belirlenmiştir. Buna göre öğretmenlerin yapılandırmacı öğrenme ortamı oluşturmalarının yüksek düzeyde olduğunu söyleyebiliriz. Alt boyut puan ortalamalarına bakıldığında öğretmenlerin yapılandırmacı öğrenme ortamı oluşturmalarının kavramsal çelişkiler alt boyutunda $(\overline{\mathrm{X}}=3.14)$ orta düzeyde, diğer alt boyutlarda yüksek düzeyde olduğu görülmektedir.

\section{4. Öğretmenlerin Yapılandırmacı Öğrenme Ortamı Oluşturma Düzeylerinin Cinsiyet ve Kıdem Değişkenlerine Ait Bulguları}

Öğretmenlerin yapılandırmacı öğrenme ortamı oluşturma düzeylerinin cinsiyet değişkenine göre farklılaşma durumlarını incelemek için yapılan bağımsız gruplar $t$-testi sonuçları Tablo 7'de verilmiştir.

Tablo 7. Ortaokul Matematik Öğretmenlerinin Yapılandırmacı Öğrenme Ortamı Oluşturma Düzeylerinin Cinsiyete Göre Bağımsız Gruplar $t$-testi Sonuçları

\begin{tabular}{|c|c|c|c|c|c|c|c|}
\hline Alt Boyutlar & Cinsiyet & $\mathbf{N}$ & $\overline{\mathbf{X}}$ & Ss & $t$ & Sd & $p$ \\
\hline \multirow{2}{*}{ Tartışma ve Görüşmeler } & Kadın & 242 & 4.05 & .69 & \multirow{2}{*}{.37} & \multirow{2}{*}{440} & \multirow{2}{*}{.707} \\
\hline & Erkek & 200 & 4.02 & .69 & & & \\
\hline \multirow{2}{*}{ Kavramsal Çelişki } & Kadın & 242 & 3.18 & 1.43 & \multirow{2}{*}{.66} & \multirow{2}{*}{440} & \multirow{2}{*}{.504} \\
\hline & Erkek & 200 & 3.09 & 1.38 & & & \\
\hline \multirow{2}{*}{ Düşünceleri Paylaşma } & Kadın & 242 & 3.95 & .67 & \multirow{2}{*}{.83} & \multirow{2}{*}{440} & \multirow{2}{*}{.405} \\
\hline & Erkek & 200 & 3.90 & .75 & & & \\
\hline \multirow{2}{*}{$\begin{array}{l}\text { Materyal ve Kaynakların Çözüme } \\
\text { Götürmesi }\end{array}$} & Kadın & 242 & 3.79 & .73 & \multirow{2}{*}{-1.92} & \multirow{2}{*}{440} & \multirow{2}{*}{.055} \\
\hline & Erkek & 200 & 3.93 & .78 & & & \\
\hline \multirow{2}{*}{$\begin{array}{l}\text { Kavram Keşfi ve Yansitma İçin } \\
\text { Motive Etme }\end{array}$} & Kadın & 242 & 4.00 & .71 & \multirow{2}{*}{.77} & \multirow{2}{*}{440} & \multirow{2}{*}{.440} \\
\hline & Erkek & 200 & 3.94 & .80 & & & \\
\hline \multirow{2}{*}{ Öğrenen İhtiyaçlarını Karşılama } & Kadın & 242 & 3.88 & .71 & \multirow{2}{*}{-1.04} & \multirow{2}{*}{440} & \multirow{2}{*}{.297} \\
\hline & Erkek & 200 & 3.95 & .74 & & & \\
\hline \multirow{2}{*}{$\begin{array}{l}\text { Anlam Oluşturma ve Gerçek } \\
\text { Yaşamla Bağlantı }\end{array}$} & Kadın & 242 & 4.10 & .68 & \multirow{2}{*}{-.69} & \multirow{2}{*}{440} & \multirow{2}{*}{.486} \\
\hline & Erkek & 200 & 4.15 & .69 & & & \\
\hline \multirow{2}{*}{ Yapılandırmacı Öğrenme Ortamı } & Kadın & 242 & 3.89 & .55 & \multirow{2}{*}{-.00} & \multirow{2}{*}{440} & \multirow{2}{*}{.996} \\
\hline & Erkek & 200 & 3.89 & .59 & & & \\
\hline
\end{tabular}

Tablo 7 incelendiğinde öğretmenlerin yapılandırmacı öğrenme ortamı oluşturma düzeylerinde cinsiyete göre ölçek toplam puanı için anlamlı farklılık görülmemektedir $\left(t_{(440)}=-.00, p>.05\right)$. Buna göre cinsiyetin öğretmenlerin yapılandırmacı öğrenme ortamı oluşturma düzeyleri üzerinde anlamlı bir etkisinin olmadığı söylenebilir. Diğer taraftan tüm alt boyutlarda da anlamlı farkl11ık görülmemektedir.

Öğretmenlerin yapılandırmacı öğrenme ortamı oluşturma düzeylerinin kıdem değişkenine göre farklılaşma durumlarını incelemek için yapılan tek yönlü ANOVA sonuçları Tablo 8'de verilmiştir.

Tablo 8. Ortaokul Matematik Öğretmenlerinin Yapılandırmacı Öğrenme Ortamı Oluşturmalarının Kıdem Değişkenine Göre Tek Yönlü ANOVA Sonuçları

\begin{tabular}{clcccccccc}
\hline \multicolumn{1}{c}{ Alt Boyutlar } & Kıdem & $\mathbf{N}$ & $\overline{\mathbf{X}}$ & Ss & Sd & $\mathbf{F}$ & $\boldsymbol{p}$ & Fark & $\eta^{2}$ \\
\hline \multirow{3}{*}{ Tartışma ve Görüşmeler } & $1.1-5$ yıll & 106 & 4.03 & .62 & & & & & \\
& $2.6-10$ yıll & 147 & 3.93 & .64 & 3 & .24 & .082 & & \\
& 3.11-15 yıl & 112 & 4.14 & .64 & 3 & & & & \\
& 4.16 yıl ve üstü & 77 & 4.10 & .90 & & & & & \\
\hline
\end{tabular}


Tablo 8. (devam1)

\begin{tabular}{|c|c|c|c|c|c|c|c|c|c|}
\hline Alt Boyutlar & Kidem & $\mathbf{N}$ & $\overline{\mathbf{X}}$ & Ss & Sd & $\mathbf{F}$ & $p$ & Fark & $\eta^{2}$ \\
\hline \multirow{4}{*}{ Kavramsal Çelişkiler } & 1. $1-5 \mathrm{y} 1 \mathrm{l}$ & 106 & 3.20 & 1.43 & \multirow{4}{*}{3} & \multirow{4}{*}{3.68} & \multirow{4}{*}{.012} & \multirow{4}{*}{$2-4$} & \multirow{4}{*}{.02} \\
\hline & 2. 6-10 yil & 147 & 3.35 & 1.32 & & & & & \\
\hline & 3. $11-15 \mathrm{y} 1 \mathrm{l}$ & 112 & 3.12 & 1.40 & & & & & \\
\hline & 4. 16 yıl ve üstü & 77 & 2.70 & 1.47 & & & & & \\
\hline \multirow{4}{*}{ Düşünceleri Paylaşma } & 1. $1-5 \mathrm{y} 1 \mathrm{l}$ & 106 & 3.82 & .69 & \multirow{4}{*}{3} & \multirow{4}{*}{1.53} & \multirow{4}{*}{.204} & & \\
\hline & 2. $6-10 \mathrm{y} 1 \mathrm{l}$ & 147 & 3.91 & .65 & & & & & \\
\hline & 3. $11-15 \mathrm{y} 1 \mathrm{l}$ & 112 & 4.00 & .70 & & & & & \\
\hline & 4. 16 yıl ve üstü & 77 & 4.00 & .83 & & & & & \\
\hline \multirow{4}{*}{$\begin{array}{l}\text { Materyal ve } \\
\text { Kaynakların Çözüme } \\
\text { Götürmesi }\end{array}$} & 1. $1-5 \mathrm{y} 1 \mathrm{l}$ & 106 & 3.91 & .69 & \multirow{4}{*}{3} & \multirow{4}{*}{.76} & \multirow{4}{*}{.513} & & \\
\hline & 2. $6-10 \mathrm{y} 1 \mathrm{l}$ & 147 & 3.84 & .74 & & & & & \\
\hline & 3. $11-15 \mathrm{y} 1 \mathrm{l}$ & 112 & 3.78 & .85 & & & & & \\
\hline & 4. 16 yıl ve üstü & 77 & 3.93 & .74 & & & & & \\
\hline \multirow{4}{*}{$\begin{array}{l}\text { Kavram Keşfi ve } \\
\text { Yansitma İçin Motive } \\
\text { Etme }\end{array}$} & 1. $1-5 \mathrm{y} 11$ & 106 & 3.97 & .75 & \multirow{4}{*}{3} & \multirow{4}{*}{.74} & \multirow{4}{*}{.528} & & \\
\hline & 2. $6-10 \mathrm{yll}$ & 147 & 3.91 & .69 & & & & & \\
\hline & 3. 11-15 y1l & 112 & 3.99 & .82 & & & & & \\
\hline & 4. 16 yll ve üstü & 77 & 4.06 & .75 & & & & & \\
\hline \multirow{4}{*}{$\begin{array}{l}\text { Öğrenen İhtiyaçlarını } \\
\text { Karşılama }\end{array}$} & 1. 1-5 y1l & 106 & 3.84 & .82 & \multirow{4}{*}{3} & \multirow{4}{*}{.77} & \multirow{4}{*}{.509} & & \\
\hline & 2. $6-10 \mathrm{y} 1 \mathrm{l}$ & 147 & 3.89 & .64 & & & & & \\
\hline & 3. $11-15 \mathrm{y} 1 \mathrm{l}$ & 112 & 3.97 & .75 & & & & & \\
\hline & 4. 16 yll ve üstü & 77 & 3.96 & .70 & & & & & \\
\hline \multirow{4}{*}{$\begin{array}{l}\text { Anlam Oluşturma ve } \\
\text { Gerçek Yaşamla } \\
\text { Bağlantı }\end{array}$} & 1. 1-5 y1l & 106 & 4.12 & .67 & \multirow{4}{*}{3} & \multirow{4}{*}{49} & \multirow{4}{*}{.685} & & \\
\hline & 2. 6-10 y1l & 147 & 4.07 & .69 & & & & & \\
\hline & 3. $11-15$ y1l & 112 & 4.16 & .66 & & & & & \\
\hline & 4. 16 yıl ve üstü & 77 & 4.18 & .73 & & & & & \\
\hline \multirow{4}{*}{$\begin{array}{l}\text { Yapılandırmacı } \\
\text { Öğrenme Ortamı }\end{array}$} & 1. $1-5 \mathrm{y} 1 \mathrm{l}$ & 106 & 3.87 & .54 & \multirow{4}{*}{3} & \multirow{4}{*}{.29} & \multirow{4}{*}{.828} & & \\
\hline & 2. $6-10 \mathrm{y} 1 \mathrm{l}$ & 147 & 3.87 & .56 & & & & & \\
\hline & 3. $11-15$ y1l & 112 & 3.93 & .56 & & & & & \\
\hline & 4. 16 y1l ve üstü & 77 & 3.91 & .64 & & & & & \\
\hline
\end{tabular}

Tablo 8 incelendiğinde öğretmenlerin yapılandırmacı öğrenme ortamı oluşturma düzeylerinde kıdeme göre ölçek toplam puanı için anlamlı farklılık görülmemektedir $\left(\mathrm{F}_{(3,438)}=.29\right.$, p $\left.>.05\right)$. Buna göre mesleki deneyimin matematik öğretmenlerinin yapılandırmacı öğrenme ortamı oluşturmalarında anlamlı bir etkisinin olmadığı söylenebilir. Alt boyut puan ortalamalarına bakıldığında kavramsal çekişiler alt boyutunda anlamlı farklılık $\left(\mathrm{F}_{(3,438)}=3.68, \mathrm{p}<.05\right)$ elde edilmiştir. Test sonucu elde edilen etki büyüklüğüne göre bu farkın düşük düzeyde olduğu görülmektedir. Diğer alt boyutlarda anlamlı farklılık görülmemektedir.

Kavramsal çelişkiler alt boyutunda elde edilen anlamlı farkın kaynağını belirlemek için Scheffe testi yapılmıştır. Yapılan Scheffe testi sonucuna göre sürekli ve amaçlı düşünme alt boyutunda 6-10 y1l kıdeme sahip olan matematik öğretmenlerinin $(\bar{X}=3.35), 16$ yıl ve üstü yıl kıdeme sahip olan matematik öğretmenlerinden $(\bar{X}=2.70)$ daha yüksek yapılandırmacı öğrenme ortamı oluşturma düzeyine sahip oldukları görülmektedir.

\subsection{Ortaokul Matematik Öğretmenlerinin Yansıtıcı Düşünme Eğilimleri ile Yapılandırmacı Öğrenme Ortamı Oluşturma Düzeyleri Arasındaki İlişkiye ve Bu İlişkinin Gücüne Ait Bulgular}

Ortaokul matematik öğretmenlerinin yansıtıcı düşünme eğilim düzeyleri ile yapılandırmacı öğrenme ortamı oluşturma düzeyleri arasındaki ilişkiyi belirlemek için Pearson korelasyon analizi yapılmıştır. Korelasyon sonucundan elde edilen bulgular Tablo 9'da verilmiştir. 
Ortaokul Matematik Öğretmenlerinin Yansıtıcı Düşünme Eğilimleri ile Yapılandırmacı Öğrenme Ortamı Oluşturma Düzeyleri Arasındaki İlişki

Tablo 9. Yansıtıcı Düşünme Eğilimi İle Yapılandırmacı Öğrenme Ortamı Alt Boyutlarına İlişkin Pearson Korelasyon Analizi Sonuçları

\begin{tabular}{|c|c|c|c|c|c|c|c|c|c|c|c|c|c|}
\hline & 1 & 2 & 3 & 4 & 5 & 6 & 7 & 8 & 9 & 10 & 11 & 12 & 13 \\
\hline 1 & & & & & & & & & & & & & \\
\hline 2 & $.34 * *$ & & & & & & & & & & & & \\
\hline 3 & $.33^{* *}$ & $.65^{* *}$ & & & & & & & & & & & \\
\hline 4 & $.26 * *$ & $.27 * *$ & $.33 * *$ & & & & & & & & & & \\
\hline 5 & $.37 * *$ & $.38 * *$ & $.47 * *$ & $.40 * *$ & & & & & & & & & \\
\hline 6 & $.28 * *$ & $.26 * *$ & $.35 * *$ & $.31 * *$ & $.65^{* *}$ & & & & & & & & \\
\hline 7 & $.42 * *$ & $.34 * *$ & $-.33 * *$ & $.28^{* *}$ & $.51^{* *}$ & $.51 * *$ & & & & & & & \\
\hline 8 & $-.09 *$ & $-.09 *$ & $-.12 * *$ & .01 & -.08 & .06 & -.04 & & & & & & \\
\hline 9 & $.29 * *$ & $.29 * *$ & $.27 * *$ & $.24 * *$ & $.52 * *$ & $.54 * *$ & $.69 * *$ & -.02 & & & & & \\
\hline 10 & $.23 * *$ & $.20^{* *}$ & $.15^{* * *}$ & $.12 *$ & $.33 * *$ & $.36^{* *}$ & $.55^{* *}$ & -.02 & $.62 * *$ & & & & \\
\hline 11 & $.30 * *$ & $.31 * *$ & $.29 * *$ & $.22 * *$ & $.49^{* *}$ & $.44^{* *}$ & $.67 * *$ & -.08 & $.70 * *$ & $.75^{* * *}$ & & & \\
\hline 12 & $.34 * *$ & $.28 * *$ & $.26^{* * *}$ & $.24 * *$ & $.44 * *$ & $.43 * *$ & $.67 * *$ & -.05 & $.65^{* *}$ & $.66^{* *}$ & $.80^{* *}$ & & \\
\hline 13 & $.34 * *$ & $.28 * *$ & $.25 * *$ & $.26^{* *}$ & $.45^{* *}$ & $.46^{* *}$ & $.68 * *$ & $-.10^{*}$ & $.65^{* *}$ & $.62 * *$ & $.76^{* *}$ & $.79 * *$ & \\
\hline
\end{tabular}

Not: 1: Sürekli ve amaçlı düşünme, 2: Açık fikirlilik, 3: Sorgulayıcı ve etkili öğretim, 4: Öğretim sorumluluğu ve bilimsellik, 5: Araştırmacı, 6: Öngörülü ve içten olma, 7: Tartışmalar ve görüşmeler, 8: Kavramsal çelişkiler, 9: Düşünceleri paylaşma, 10: Materyal ve kaynakların çözüme götürmesi, 11: Kavram keşfi ve yansıtma için motive etme, 12: Öğrenen ihtiyaçlarını karşılama, 13: Anlam oluşturma ve gerçek yaşamla bağlantı

Tablo 9 incelendiğinde yansıtıcı düşünme eğilim alt boyutları ile yapılandırmacı öğrenme ortamı alt boyutları arasındaki ilişkilerin çoğunluğu .01 düzeyinde anlamlılık göstermektedir. Korelasyon analizi sonucunda alt boyutlar arasında yüksek düzeyde bir ilişki görülmemiştir. Elde edilen bulgulara göre en yüksek ilişki öngörülü ve içten olma alt boyutu ile düşünceleri paylaşma alt boyutu arasındadır $(\mathrm{r}=.54)$. Bu ilişki pozitif yönlü orta düzey bir ilişkidir.

Yansitıc1 düşünme ölçeği sürekli ve amaçlı düşünme alt boyutu ile tartışma ve görüşmeler $(\mathrm{r}=.42)$, anlam oluşturma ve gerçek yaşamla bağlantı $(\mathrm{r}=.34)$, öğrenen ihtiyaçlarını karşılama $(\mathrm{r}=34)$, yansıtma ve kavram keşfi için motive etme $(\mathrm{r}=30)$ ve yapılandırmacı alt boyutları ile pozitif yönlü orta düzey bir ilişki; düşünceleri paylaşma $(\mathrm{r}=.29)$, materyal ve kaynakların çözüme götürmesi $(\mathrm{r}=.23)$ ve yapılandırmacı alt boyutlarında pozitif yönlü zayıf düzey bir ilişki vardır. Kavramsal çelişkiler ( $\mathrm{r}=-.09)$ alt boyutu ile negatif yönlü zayıf bir ilişki vardır.

Yansıtıcı düşünme ölçeği açık fikirlilik alt boyutu ile tartışma ve görüşmeler ( $\mathrm{r}=.34)$, yansıtma ve kavram keşfi için motive etme $(\mathrm{r}=.31)$, yapılandırmacı alt boyutları arasında pozitif yönlü orta düzey bir ilişki; düşünceleri paylaşma ( $\mathrm{r}=.29)$, öğrenen ihtiyaçlarını karşılama $(\mathrm{r}=.28)$, anlam oluşturma ve gerçek yaşamla bağlantı $(\mathrm{r}=.28)$, materyal ve kaynakların çözüme götürmesi $(\mathrm{r}=.20)$ ve yapılandırmacı alt boyutlarında pozitif yönlü zayıf bir ilişki vardır. Kavramsal çelişkiler $(\mathrm{r}=-.09)$ alt boyutu ile negatif yönlü zayıf bir ilişki vardır.

Yansıtıcı düşünme ölçeği sorgulayıcı ve etkili öğretim alt boyutu ile tartışma ve görüşmeler $(\mathrm{r}=.33)$ ve yapılandırmacı alt boyutu arasında pozitif yönlü orta düzey bir ilişki; yansıtma ve kavram keşfi için motive etme $(\mathrm{r}=.29)$, düşünceleri paylaşma $(\mathrm{r}=.27)$, öğrenen ihtiyaçlarını karşılama $(\mathrm{r}=.26)$, anlam oluşturma ve gerçek yaşamla bağlantı $(\mathrm{r}=.25)$, materyal ve kaynakların çözüme götürmesi $(\mathrm{r}=.15)$ ve yapılandırmacı alt boyutları arasında pozitif yönlü zayıf bir ilişki vardır. Kavramsal çelişkiler $(r=-.12)$ alt boyutu ile negatif yönlü zayıf bir ilişki vardır. 
Yansitıcı düşünme ölçeği araştırmacı alt boyutu ile düşünceleri paylaşma $(r=.52)$, tartışma ve görüşmeler $(\mathrm{r}=.51)$, yansitma ve kavram keşfi için motive etme $(\mathrm{r}=.49)$, anlam oluşturma ve gerçek yaşamla bağlantı $(\mathrm{r}=.45)$, öğrenen ihtiyaçlarını karşılama $(\mathrm{r}=.44)$, materyal ve kaynakların çözüme götürmesi $(\mathrm{r}=.33)$ ve yapılandırmacı alt boyutları arasında pozitif yönlü orta düzey bir ilişki; çelişkiler $(r=-.08)$ alt boyutu arasında negatif yönlü zayıf bir ilişki vardır.

Yansitıcı düşünme ölçeği öngörülü ve içten olma alt boyutu ile düşünceleri paylaşma $(\mathrm{r}=.54)$, tartışma ve görüşmeler $(\mathrm{r}=.51)$, anlam oluşturma ve gerçek yaşamla bağlantı $(\mathrm{r}=.46)$, yansıtma ve kavram keşfi için motive etme $(\mathrm{r}=.44)$, öğrenen ihtiyaçlarını karşılama ( $\mathrm{r}=.43)$, materyal ve kaynakların çözüme götürmesi $(\mathrm{r}=.36)$ ve yapılandırmacı alt boyutları ile pozitif yönlü orta düzey bir ilişki; kavramsal çelişkiler $(r=.06)$ alt boyutu arasında pozitif yönlü zayıf bir ilişki vardir.

Yansitıcı düşünme ölçeği öğretim sorumluluğu ve bilimsellik alt boyutu ile tartışmalar ve görüşmeler $(\mathrm{r}=.28)$, anlam oluşturma ve gerçek yaşamla bağlantı $(\mathrm{r}=.26)$, öğrenen ihtiyaçlarını karşılama $(\mathrm{r}=.24)$, düşünceleri paylaşma $(\mathrm{r}=.24)$, kavram keşfi ve yansıtma için motive etme $(\mathrm{r}=.22)$, materyal ve kaynakların çözüme götürmesi $(\mathrm{r}=.12)$ ve kavramsal çelişkiler $(\mathrm{r}=.01)$ alt boyutları ile pozitif yönlü zayıf ilişkiler vardır.

Ortaokul matematik öğretmenlerinin sürekli ve amaçlı düşünme, açık fikirlilik, sorgulayıcı ve etkili öğretim, öğretim sorumluluğu ve bilimsellik, araştırmacı ve öngörülü ve içten olma eğilimlerinin yapılandırmacı öğrenme ortamı oluşturma düzeylerini yordama gücünü belirlemek amacıyla yapılan çoklu regresyon analizinde öncelikle bu analiz için gerekli varsayımların sağlanıp sağlanamadığı kontrol edilmiştir. Normallik, doğrusallık, çoklu ortak doğrusallık ve eş varyanslılık varsayımları incelenmiş ve tüm değerlerin referans aralığında olduğu (VIF değerleri 1.24 ile 2.13 arasında, tolerance değerleri .46 ile .80 arasında değişmektedir), herhangi bir varsayımın ihlal edilmediği görülmüştür. Analiz sonucunda elde edilen bulgular Tablo 10'da verilmiştir.

Tablo 10. Sürekli ve Amaçlı Düşünme, Açık Fikirlilik, Sorgulayıcı ve Etkili Öğretim, Öğretim Sorumluluğu ve Bilimsellik, Araştırmacı, Öngörülü ve İçten Olma Eğilimlerinin Yapılandırmacı Öğrenme Ortamı Oluşturmalarını Yordama Gücüne İlişkin Çoklu Regresyon Analizi Sonuçları

\begin{tabular}{lccccccc}
\hline \multicolumn{1}{c}{ Değişken } & $\mathbf{B}$ & $\begin{array}{c}\text { Standart } \\
\text { Hata }\end{array}$ & $\boldsymbol{\beta}$ & $\boldsymbol{t}$ & $\boldsymbol{p}$ & $\begin{array}{c}\text { İkili } \\
\mathbf{r}\end{array}$ & $\begin{array}{c}\text { Kısmi } \\
\mathbf{r}\end{array}$ \\
\hline Sabit & .04 & .33 & - & .13 & .893 & - & - \\
Sürekli ve amaçlı düşünme & .21 & .06 & .15 & 3.59 & .000 & .352 & .170 \\
Açık fikirlilik & .17 & .06 & .14 & 2.85 & .005 & .312 & .135 \\
Sorgulayıc1 ve etkili öğretim & -.11 & .05 & -.10 & -1.88 & .060 & .278 & -.090 \\
Öğretim sorumluluğu ve & .04 & .06 & .02 & .63 & .528 & .270 & .030 \\
bilimsellik & .23 & .06 & .20 & 3.74 & .000 & .513 & .177 \\
Araştırmac1 & .33 & .04 & .35 & 7.01 & .000 & .542 & .319 \\
Öngörülü ve içten olma & $\mathrm{R}^{2}=.375$ & & & & & & \\
\hline $\mathrm{R}=.613$ & $p=.000$ & & & & & & \\
$\mathrm{~F}_{(6,435)}=43.57$ & & & & & & & \\
\hline
\end{tabular}

Tablo 10'da sunulan bulgulara göre, sürekli ve amaçlı düşünme, açık fikirlilik, sorgulayıcı ve etkili öğretim, öğretim sorumluluğu ve bilimsellik, araştırmacı, öngörülü ve içten olma değişkenlerinin, ortaokul matematik öğretmenlerinin yapılandırmacı öğrenme ortamı oluşturma düzeylerini yordamak amacıyla oluşturulan çoklu doğrusal regresyon modelinin anlamlı olduğu $\left(\mathrm{F}_{(6,435)}=43.57, \mathrm{p}<.01\right)$, model kapsamındaki bağımsız değişkenlerin yapılandırmacı öğrenme ortamı oluşturma düzeyindeki varyansın yaklaşık \%37'sini açıkladığı görülmektedir. 
Bağımsız değişkenlerin göreli önem sırasını belirlemek amacıyla standartlaştırılmış regresyon katsayıları incelenmiştir. Buna göre yordayıcı değişkenlerin, yapılandırmacı öğrenme ortamı oluşturma düzeyi üzerine göreli önem sırası, öngörülü ve içten olma $(\beta=.35)$, araştırmac1 $(\beta=.20)$, sürekli ve amaçlı düşünme $(\beta=.15)$, açık fikirlilik $(\beta=.14)$, öğretim sorumluluğu ve bilimsellik $(\beta=.02)$ ve sorgulayıcı ve etkili öğretim $(\beta=-.10)$ şeklindedir. Katsayılarının istatistiksel anlamlılığı incelendiğinde, sürekli ve amaçlı düşünme $(\mathrm{p}<.01)$, açık fikirlilik $(\mathrm{p}<.01)$, araştırmacı $(\mathrm{p}<.01)$ ve öngörülü ve içten olma $(\mathrm{p}<.01)$ değişkenlerinin, yapılandırmac1 öğrenme ortamı oluşturma düzeyinin anlamlı yordayıcıları olduğu görülmektedir.

\section{Tartışma ve Sonuçlar}

Araştırmanın birinci alt problemi kapsamında öğretmenlerin yansıtıcı düşünme eğilim düzeylerinin ne olduğu araştırılmıştır. Elde edilen sonuçlara göre, ortaokul matematik öğretmenlerinin yüksek düzeyde yansıtıcı düşünme becerilerine sahip olduğu görülmüştür. Öğretmenlerin bu becerilere yüksek düzeyde sahip olmaları, yapılandırmacı programın amaçlarına ulaşmasında önemli bir kolaylaştırıcı bir faktör olarak görülebilir. Farklı branşlardaki öğretmenlerin yansitıcı düşünme eğilimlerini inceleyen araştırmalarda da benzer sonuçlara ulaşıldığı görülmüştür. Örneğin, Aslan (2009) ve Üstün (2011) sınıf öğretmenlerinin, Y1ldız (2013) din kültürü ve ahlak bilgisi öğretmenlerinin, Aykar (2019) ise okul öncesi öğretmenlerinin yansıtıcı düşünme eğilimlerinin yüksek olduğunu belirtmişlerdir.

Araştırma sonucunda öğretmenlerin yansıtıcı düşünme eğilimlerinin sadece açık fikirlilik alt boyutunda cinsiyete göre anlamlı bir farklılık olduğu, kadın öğretmenlerin açık fikirlilik puanlarının erkek öğretmenlere göre anlamlı düzeyde yüksek olduğu bulunmuştur. Elde edilen bu sonuç, kadın öğretmenlerin erkek öğretmenlere göre olaylara daha esnek yaklaşabildiklerini ve öğrencilerden gelen tepki ve sorulara daha açık olabildiklerini göstermektedir. Yansıtıc1 düşünmenin diğer alt boyutlarında cinsiyete göre anlamlı bir fark bulunmamıştır. Elde edilen bu sonuç Kılınç'ın (2010) araştırmasındaki yansıtıcı düşünmede cinsiyete göre bütüncül olarak anlamlı farklılık elde edilmemiş olsa da açık fikirlilik alt boyutunda kadın öğretmenler lehine anlamlı farklılık olduğuna yönelik bulgularıyla örtüşmektedir. Aynı şekilde Aslan (2009) ve Yıldız'ın (2013) açık fikirlilik alt boyutunda kadınlar lehine anlamlı bir farklılık olduğuna yönelik bulguları da bu çalışma sonucuyla benzerlik göstermektedir.

Araştırmada kıdeme göre öğretmenlerin yansıtıcı düşünme eğilimi düzeylerinde anlamlı bir farklılaşma olduğu, kıdem arttıkça yansıtıcı düşünme eğiliminin de arttığı bulunmuştur. $\mathrm{Bu}$ sonuçlara göre kıdemi daha fazla olan öğretmenlerin mesleki tecrübelerini daha iyi değerlendirdiği, kıdeme göre yansıtıcı düşünmenin bileşenlerinden olan öngörülü ve içten olma düzeylerinin de arttı̆̆ı, sorgulayıcı ve etkili öğretim, öğretim sorumluluğu ve bilimsellik ile sürekli ve amaçlı düşünme boyutlarında artış olduğu söylenebilir. Araştırmada elde edilen bu bulgu, Kılınç'ın (2010) ilköğretim birinci ve ikinci kademe öğretmenlerinin meslekteki kıdemleri arttıkça yansıtıcı düşünme eğilimlerinin de arttığı, Aykar'ın (2019) 21 yıl ve üstü deneyime sahip öğretmenlerin yansıtıcı düşünme becerilerinin daha yüksek olduğuna yönelik bulgularıyla örtüşürken Karadağ'ın (2010) sosyal bilgiler öğretmenlerinin yansıtıcı düşünme eğilimlerinin kıdeme göre değişmediğine yönelik sonuçlarıile farklılık göstermektedir.

Çalışmada yansıtıcı düşünme ile ilgili hizmet içi eğitim alma durumuna göre öğretmenlerin yansıtıcı düşünme eğilimlerinde anlamlı bir farklılık olmadığı bulunmuştur. Elde edilen bu bulgu, Meral (2009) ve Aykar'ın (2019) yansıtıcı düşünme ile ilgili eğitimlerin öğretmenlerin yansıtıcı düşünme eğilimlerine etkisinin olmadığına yönelik sonuçlarıyla örtüşmektedir. Hizmet içi eğitimlerin öğretmenlerin mesleki gelişimine olumlu katkılar sağladığ bilinen bir durumdur ancak yansıtıcı düşünme eğilimleri konusunda hizmet içi eğitim alan ve almayan öğretmenlerin 
birbirine yakın puanlar alması verilen hizmet içi eğitimin niteliğin yeterli düzeyde olmamasından kaynaklanmış olabilir.

Araştırmada öğretmenlerin yapılandırmacı öğrenme ortamı oluşturma düzeylerinin kavramsal çelişkiler alt boyutu hariç diğer boyutlarda yüksek olduğu, kavramsal çelişkiler boyutunda ise orta düzeyde olduğu bulunmuştur. İlgili literatür incelendiğinde Yılmaz (2006) sınıf öğretmenlerinin, Işı (2014) ise ortaokul öğretmenlerinin yapılandırmacı öğrenme ortam1 oluşturma düzeylerinin yüksek olduğu, ancak kavramsal çelişkiler düzeylerinin düşük olduğu sonucuna ulaşmıştır. Bu yönüyle elde edilen bu iki sonucun çalışmanın sonuçları ile paralellik gösterdiği söylenebilir. Karagöz (2016) ise tartışmalar ve görüşmeler ve öğrenen ihtiyaçlarını karşılama alt boyut düzeylerinin orta, kavramsal çelişkiler düzeylerinin düşük olduğu ancak diğer alt boyutların yüksek düzeyde olduğu sonucuna ulaşmıştır. Çınar (2010), Aydın (2010), İlgen (2010) ve Tural'ın (2009) çalışmalarından elde ettiği sonuçlar araştırma bu çalışmanın sonuçlarını desteklemektedir. Çınar (2010) sınıf ve branş öğretmenlerinin yapılandırmacı öğrenmeye ilişkin yeterliklerinin yüksek olduğunu belirtmiştir. Aydın (2010) ise ortaokul branş öğretmenlerinin yapılandırmacı öğrenme ortamı oluşturmada başarılı olduklarını ifade etmiştir. Tural'a (2009) göre sosyal bilgiler öğretmenlerinin yapılandırmacı öğretime karşı tutumlarının yüksek olması ve İlgen'e (2010) göre sınıf öğretmenlerinin yapılandırmacı öğrenme ortamını değerlendirme düzeylerinin yüksek olması çalışma bulgularını destekler niteliktedir. Elde edilen bu sonuçlara göre yapılandırmacı eğitim anlayışına göre öğretmenlerin öğrenme ortamının nasıl düzenlenmesi konusunda yeterli kavramsal bilgi ve birimime sahip oldukları söylenebilir. Bununla birlikte öğretmenlerin yapılandırmacılıkla ilgili sahip oldukları eğilimleri ne düzeyde uygulamaya geçirdikleri konusu tartışmalıdır. Örneğin Fidan (2010) tarafından yapılan bir araştırmada, sınıf öğretmenlerinin yapılandırmacı öğretimin gerektirdiği niteliklere sahip olduklarını ancak gözlem sonuçlarına göre derslerinde yapılandırmacı uygulamalara yer vermedikleri belirlenmiştir. Benzer şekilde Mertoğlu (2011), fen bilgisi öğretmenlerinin kendilerini yapılandırmacı yaklaşıma uygun ders işleme algılarının yüksek olduğunu ancak uygulamada geleneksel yaklaşıma uygun davranışlar sergilediklerini ifade etmiştir. Ortaya çıkan bu sonuçlar, öğretmenlerin kendilerini yapılandırmacı öğrenme ortamı oluşturmada kavramsal yeterlikte görseler de teorik olan bu bilgileri uygulamaya aktarmada yetersiz kaldıklarını göstermektedir.

Çalışmada öğretmenlerin cinsiyete göre yapılandırmacı öğrenme ortamı oluşturma düzeylerinde anlamlı fark olmadığı, kadın ve erkek öğretmenlerin benzer yapılandırmacı öğrenme ortamları oluşturdukları bulunmuştur. Çalışmadan elde edilen bu sonuçlar, Yılmaz (2006), İlgen (2010), Fidan (2010), Aksoy (2011) ve Karagöz'ün (2016) cinsiyete göre yapılandırmacı öğrenme ortamı oluşturmada anlamlı bir fark olmadığına yönelik sonuçlarıyla tutarlılık göstermektedir.

Çalışmada mesleki kıdeme göre, öğretmenlerin yapılandırmacı öğrenme ortamı oluşturma düzeylerine anlamlı bir farklılığın olmadığı bulunmuştur. Bu sonuçları, Yılmaz (2006), İlgen (2010) ve Fidan'ın (2010) kıdeme göre, yapılandırmacı öğrenme ortamı oluşturma düzeyinde anlamlı bir farklılığın olmadığına yönelik sonuçları desteklemektedir. Bununla birlikte kıdeme göre farklı sonuçların elde edildiği çalışmalar da bulunmaktadır. Örneğin, Aksoy (2011) ortaöğretim öğretmenlerinin kıdemleri arttıkça yapılandırmacı öğrenme ortamı oluşturma algılarının da arttığ öğretmenlerinden mesleki deneyimi az olanların yapılandırmacı öğrenmeye daha olumlu yaklaştıklarını bulmuştur. Benzer şekilde Karagöz (2016) mesleki deneyimi 1-5 yıl aralığında olan öğretmenlerin yapılandırmacı ögrenme ortamı oluşturma düzeylerinin deneyimi fazla olan öğretmenlere göre fazla olduğunu bulmuştur.

Çalışmada ortaokul matematik öğretmenlerinin yansıtıcı düşünme eğilimleri ile yapılandırmacı öğrenme ortamı oluşturma düzeyleri arasında pozitif yönde orta düzeyde ve anlamlı bir ilişki olduğu sonucuna ulaşılmıştır. Bu sonuca göre, ortaokul matematik öğretmenlerinin yansıtıcı 
düşünme eğilim düzeyleri arttıkça yapılandırmacı öğrenme ortamı oluşturma düzeyleri de artmaktadır. Yansıtıcı düşünmenin bileşenleri olan amaçlı düşünme, açık fikirli, sorgulayıcı, öngörülü ve içten olma, araştırmacı ve bilimsel olma gibi özellikler yapılandırmacı yaklaşımla ilişkilidir. $\mathrm{Bu}$ özelliklerin artması yapılandırmacı öğrenme ortamlarının oluşturulmasını kolaylaştırmaktadır. Bu çalışmadan elde edilen sonuçlar, Aykar (2019) tarafından yapılan ve okul öncesi öğretmenlerinde yansitıcı düşünme beceri düzeylerinin öğretim uygulamalarını olumlu etkilediği, Yıldırım'ın (2019) sınıf öğretmeni adaylarının yansıtıcı düşünme eğilimleri ile yapılandırmacı öğrenme ve öğretme anlayışları arasında pozitif anlamlı bir ilişki olduğu, Köksal'ın (2006) yansıtıcı düşünme eğitiminin öğrenme öğretme süreçlerine olumlu katkılarının olduğuna yönelik sonuçlarıyla tutarlılık göstermektedir.

$\mathrm{Bu}$ çalışmadan elde edilen sonuçlar genel olarak değerlendirildiğinde ortaokul matematik öğretmenlerinin yansitıcı düşünme eğilimlerinin ve yapılandırmacı öğrenme ortamı oluşturma düzeylerinin yüksek olduğu görülmektedir. Ancak bu çalışmadan elde edilen bulgular özbildirime dayalı ölçeklerle toplanmıştır. Yukarıda sonuçları verilen çeşitli araştırmalarda da görüldüğü gibi, öğretmenlerin yansıtıcı düşünme ve yapılandırmacı öğrenme ortamı oluşturma düzeylerinin yüksek olduğunu beyan etmelerine rağmen sınıf içi uygulamalara bu becerileri yeterince yansıtmadıkları görülmektedir. Dolayısıyla ölçeklerle toplanan verilerin gözlem ve görüşme gibi diğer tekniklerden elde edilen bulgularla birlikte değerlendirilmesi faydalı olabilir.

Yapılandırmacı yaklaşımın uygulanmasını kolaylaştıran ve matematik öğretmenlerin mesleki gelişimlerinde önemli rol oynayan ve yansitıcı düşünmenin hizmet öncesi ve hizmet içi öğretmen eğitim programlarının önemli bir parçası haline getirilmesi sağlanmalıdır. Ayrıca matematik ders kitaplarında, yansıtıcı düşünme becerilerini geliştirecek uygulama ve etkinliklere daha fazla yer verilmesi bu becerilerin uygulamaya aktarılmasına yardımcı olabilir.

\section{Kaynaklar}

Agustan, S., Juniati, D., \& Siswono, T. Y. E. (2017). Reflective thinking in solving an algebra problem: A case study of field independent-prospective teacher. Journal of Physics: Conference Series, 893(1),1-6. https://doi.org/10.1088/1742-6596/893/1/012002

Aksoy, R. (2011). Ortaöğretim öğretmenlerinin ögretmen öz-yeterlik ve yapılandırmact ögrenme ortamı düzenleme becerilerine yönelik algıları (Yayınlanmamış yüksek lisans tezi). Muğla Üniversitesi Eğitim Bilimleri Enstitüsü, Muğla.

Aldahmash, A. H., Alshalhoub, S. A., \& Naji, M. A. (2021). Mathematics teachers' reflective thinking: Level of understanding and implementation in their professional practices. Plos One, 16(10), 1-17. https://doi.org/10.1371/journal.pone.0258149

Allen, R. M., \& Casbergue, R. M. (1997). Evolution of novice through expert teachers' recall: Implications for effective reflection on practice. Teaching and Teacher Education, 13(7), 741-755.

Aslan, G. (2009). Sınıf öğretmenlerinin yansıtıcı düşünme eğilimleri ile sürekli kaygı düzeyleri arasındaki iliş̧kinin incelenmesi (Yayınlanmamış yüksek lisans tezi). Yeditepe Üniversitesi Sosyal Bilimler Enstitüsü, İstanbul.

Aydın, M. (2010). Illkögretim okullarında görev yapan öğretmenlerin yapılandırmacı sınıf ortamlarına yönelik değerlendirmeleri (Yayınlanmamış yüksek lisans tezi). Yedi Tepe Üniversitesi Sosyal Bilimler Enstitüsü, İstanbul.

Aydın, M., \& Çelik T. (2013). Sosyal bilgiler öğretmen adaylarının yansıtıcı düşünme becerilerinin bazı değişkenler açısından incelenmesi. Pamukkale Üniversitesi Ĕgitim Fakültesi Dergisi, 34(34), 169-181. 
Aykar, A. (2019). Okul öncesi ögretmenlerinin yansitıcı düşünmeleri ve ögretim uygulamalarındaki gelişimlerinin incelenmesi (Yayınlanmamış yüksek lisans tezi). Çanakkale Onsekiz Mart Üniversitesi Eğitim Bilimleri Enstitüsü, Çanakkale.

Bauer, N. J. (1991, October). Dewey and Schon: An analysis of reflective thinking. Paper presented at the Annual Meeting of the American Educational Studies Association in Kansas City, MO. Retrieved from https://files.eric.ed.gov/fulltext/ED344299.pdf

Battal, C. F. (2008). Yapılandırmacı yaklaşıma dayalı fen ve teknoloji programının uygulanmasına ilişkin ögretmen görüşlerinin incelenmesi (Yayınlanmamış yüksek lisans tezi). Selçuk Üniversitesi Sosyal Bilimler Enstitüsü, Konya.

Çınar, S. (2010). Öğretmenlerin yapılandırmacı öğrenme yeterlilikleri algılarının incelenmesi (İstanbul ili- Ümraniye ilçesi örneği) (Yayınlanmamış yüksek lisans tezi). Yedi Tepe Üniversitesi Sosyal Bilimler Enstitüsü, İstanbul.

Deringöl, Y. (2019). The relationship between reflective thinking skills and academic achievement in mathematics in fourth-grade primary. International Online Journal of Education and Teaching (IOJET), 6(3), 619-628.

Dewey, J. (1993). The political writings. Cambridge: Hackett Publishing.

Dolapçıŏlu, S. D. (2007). Sinıf öğretmenlerinin yansıtıcı düşünme düzeylerinin incelenmesi (Yayınlanmamış yüksek lisans tezi). Mustafa Kemal Üniversitesi Sosyal Bilimler Enstitüsü, Hatay.

Duban, N., \& Yelken, T. Y. (2010). Öğretmen adaylarının yansıtıcı düşünme eğilimleri ve yansitıcı öğretmen özellikleriyle ilgili görüşleri. Çukurova Üniversitesi Sosyal Bilimler Enstitüsü Dergisi, 19(2), 343-360.

Erdoğan, A. (2019). Ortaöğretim ögrencilerinin problem çözmeye yönelik yansitıcı düşünme becerilerinin bazı değişkenler açısından incelenmesi (Yayınlanmamış yüksek lisans tezi). Necmettin Erbakan Üniversitesi Eğitim Bilimleri Enstitüsü, Konya.

Ergüven, S. (2011). Öğretmenlerin yansitıcı düşünme becerilerinin çeşitti değişkenler açısından incelenmesi (Yayınlanmamış yüksek lisans tezi). Niğde Üniversitesi Sosyal Bilimler Enstitüsü, Niğde.

Fer, S., \& Cırık, İ. (2006). Öğretmenlerde ve öğrencilerde, yapılandırmacı öğrenme ortamı ölçeğinin geçerlik ve güvenirlik çalışması nedir. Yeditepe Üniversitesi Eğitim Fakültesi Dergisi, 2(1), 1-26.

Fidan, N. K. (2010). Sınıf ögretmenlerinin yapılandırmacı yaklaşımın gerektirdiği niteliklere sahip olma düzeylerinin değerlendirilmesi (Afyonkarahisar ili örneği) (Yayınlanmamış doktora tezi). Gazi Üniversitesi Eğitim Bilimleri Enstitüsü, Ankara.

Gözel, E., \& Toptaş, V. (2017). Sınıf öğretmeni adaylarının matematik öğretimi yeterlik inançları ile yansıtıcı düşünme becerileri arasındaki ilişki. Cumhuriyet Uluslararası Ĕ̈itim Dergisi, 6(4), 412-425.

Gürbüz, N., \& Bozan, S. (2018). Fen bilgisi ve sosyal bilgiler öğretmen adaylarının yansitıcı düşünme düzeylerinin karşılaştırılması. Uluslararası Sosyal Araştırmalar Dergisi, $11(60), 723-727$.

Güzel, İ., Karataş, İ., \& Çetinkaya, B. (2010). Ortaöğretim matematik öğretim programlarının karşılaştırılması: Türkiye, Almanya ve Kanada. Türk Bilgisayar ve Matematik Eğitimi Dergisi, 1(3). 309-325.

Hasırcı, Ö. K., \& Sadık, F. (2011). Sınıf öğretmenlerinin yansıtıcı düşünme eğilimlerinin incelenmesi. Çukurova Üniversitesi Sosyal Bilimler Enstitüsü Dergisi, 20(2), 195-210. 
Işı, Y. (2014). Ortaokul ögretmenlerinin program yönelimleri ile yapılandırmacı öğrenme ortamı düzenleme becerileri arasındaki ilişkinin incelenmesi (Yayınlanmamış yüksek lisans tezi). Kocaeli Üniversitesi Sosyal Bilimler Enstitüsü, Kocaeli.

İlgen, H. (2010). Sinıf ögrretmenlerinin ve ilköğretim öğrencilerinin yapılandırmacı öğrenme ortamını değerlendirmeleri (Yayınlanmamış yüksek lisans tezi). Yeditepe Üniversitesi Sosyal Bilimler Enstitüsü, İstanbul.

Karadağ, M. (2010). Sosyal bilgiler öğretmenlerinin yansitıcı düşünme düzeylerinin incelenmesi (Şanlıurfa ili örneği) (Yayınlanmamış yüksek lisans tezi). Çukurova Üniversitesi Sosyal Bilimler Enstitüsü, Adana.

Karagöz, F. (2016). Ortaöğretim öğretmenlerinin yapılandırmacı öğrenme ortamlarına yönelik görüşlerinin incelenmesi: İstanbul ili Ümraniye ilçesi (Yayınlanmamış yüksek lisans tezi). Yedi Tepe Üniversitesi Eğitim Bilimleri Enstitüsü, İstanbul.

Karasar, N. (2012). Bilimsel araştırma yöntemleri (24. bask1). Ankara: Nobel Yayıncılık.

Kaya, A. (2008). Yapılandırmacı öğrenme yaklaşımını uygulayan sınıf ögrretmenleri ile bu yaklaşımı uygulamayan dal ögretmenlerinin sınıf yönetimi yaklaşımlarının karşılaştırılması (Gaziantep ili örneği) (Yayınlanmamış doktora tezi). İnönü Üniversitesi, Sosyal Bilimler Enstitüsü, Malatya.

Kılınç, H. H. (2010). İlköğretim birinci ve ikinci kademe öğretmenlerinin yansitıcı düşünme eğilimleri (Yayınlanmamış yüksek lisans tezi). Fırat Üniversitesi Sosyal Bilimler Enstitüsü, Elazığ.

Korumaz, M., \& Özkılıç, R. (2015). Yabancı dil öğretmenlerinin öğretime yönelik tutumlarının incelenmesi. Marmara Üniversitesi Atatürk Ĕ̈itim Fakültesi Ĕ̈itim Bilimleri Dergisi, 42, 299-316.

Köksal, N., \& Demirel, Ö. (2008). Yansıtıcı düşünmenin öğretmen adaylarının öğretmenlik uygulamalarına katkıları. Hacettepe Üniversitesi Eğitim Fakültesi Dergisi, 34, 189-203.

Lale, E. (2016). Ortaöğretim matematik öğretmen adaylarının yansitıcı düşünme düzeylerinin incelenmesi (Yayınlanmamış yüksek lisans tezi). Gazi Üniversitesi Eğitim Bilimleri Enstitüsü, Ankara.

Langer, A. M. (2002). Reflecting on practice: Using learning journals in higher and contunuing education. Teaching in Higher Education, 7(3), 337-351.

Lee, I. (2007). Preparing pre-service English teachers for reflective practice. ELT Journal, 61 (4), 321-329.

Meral, E. (2009). Yeni (2006) İlköğretim İngilizce programını uygulayan ögretmenlerin eleştirel ve yansitıcı düşünmeleri (Yayınlanmamış yüksek lisans tezi). Fırat Üniversitesi Sosyal Bilimler Enstitüsü, Elazığ.

Mertoğlu, H. (2011). Fen ve teknoloji öğretmenlerinin öğretim stillerinin ve yapılandırmacı ögrenme ortamına ilişkin algılarının ögretim uygulamalarına etkileri (Yayınlanmamış doktora tezi). Marmara Üniversitesi Eğitim Bilimleri Enstitüsü, İstanbul.

Mezirow, J. (1991). Transformative dimensions of adult learning. San Francisco: Jossey-Bass.

Norton, J. L. (1997). Locus control and reflective thinking in preservice teachers. Education Chula Vista, 117(3), 401-410.

Ocak, G., Ocak, İ., \& Saban Y. (2013). Sınıf öğretmenlerinin fen ve teknoloji derslerindeki yansitıcı düşünme eğilimlerinin değerlendirilmesi. Uludağ Üniversitesi Eğitim Fakültesi Dergisi, 26(1), 161-184. 
Osterman, K. F. (1999). Using constructivism and reflective practice to bridge the theory/practice gap. Educational Leadership and Administration: Teaching and Program Development, 11, 9-20.

Özden, B. (2012). Yansıtıcı düşünme uygulamalarının sınıf öğretmeni adaylarının yapılandırmacı ögrenme ortamı hazırlama becerilerine etkisi (Yayınlanmamış doktora tezi). Marmara Üniversitesi Eğitim Bilimleri Enstitüsü, İstanbul.

Saygıl1, G., \& Atahan, R. (2014). Üstün zekâlı çocukların problem çözmeye yönelik yansıtıcı düşünme becerilerinin çeşitli değişkenler bakımından incelenmesi. Süleyman Demirel Üniversitesi Fen-Edebiyat Fakültesi Sosyal Bilimler Dergisi, 2014 (31), 181-192.

Semerci, Ç. (2007). Öğretmen ve öğretmen adayları için yansıtıcı düşünme eğilimi (YANDE) ölçeğinin geliştirilmesi. Kuram ve Uygulamada Eğitim Bilimleri, 7(3), 1351-1377.

Soodmand Afshar, H., \& Farahani, M. (2018). Inhibitors to EFL teachers' reflective teaching and EFL learners' reflective thinking and the role of teaching experience and academic degree in reflection perception. Reflective Practice, 19(1), 46-67.

Şanlı, Ş. V. (2016). Öğretmen adaylarının yansıtıcı düşünme eğilimlerinin bazı değişkenler açısından değerlendirilmesi (Yayınlanmamış yüksek lisans tezi). Akdeniz Üniversitesi Eğitim Bilimleri Enstitüsü, Antalya.

Temel, Ş. (2017). Sinıf öğretmenleri ve sinıf ögretmeni adaylarının yansıtıcı düşünme eğilimlerinin çeşitli değişkenler açısından incelenmesi (Yayınlanmamış yüksek lisans tezi). Gaziantep Üniversitesi Eğitim Bilimleri Enstitüsü, Gaziantep.

Tenenbaum, G., Naidu, S., Jegede, O., \& Austin, J. (2001). Constructivist pedagogy in conventional on-campus and distance learning practice: An exploratory investigation. Learning and Instruction, 11(2), 87-111.

Thahir, A., Komarudin, K., Hasanah, U. N. \& Rahmahwaty, R. (2019). MURDER Learning and self efficacy models: Impact on mathematical reflective thingking ability. Journal for the Education of Gifted Young Scientists, 7(4), 1123-1135. DOI: 10.17478/jegys.594709

Töman U., \& Çimer S. O. (2017). Öğretmen adaylarının yansıtıcı düşünme becerilerindeki gelişimin öğretim sürecinin planlanması boyutunda incelenmesi. Uluslararası Eğitim Bilimleri Dergisi, 4(13), 1-28.

Tural, A. (2009). Illköğretim ikinci kademe sosyal bilgiler ögrretmenlerinin yapılandırmacı ögrenme yaklaşımına ilişkin görüşleri (Yayınlanmamış yüksek lisans tezi). Gazi Üniversitesi Eğitim Bilimleri Enstitüsü, Ankara.

Ülker, M. (2019). Öz düzenleme ve yansıtıcı düşünmenin matematik başarısına etkisinin incelenmesi (Yayınlanmamış yüksek lisans tezi). Manisa Celal Bayar Üniversitesi Sosyal Bilimler Enstitüsü, Manisa.

Üstün, G. (2011). Sinıf ögretmenlerinin yansıtıcı düşünme eğilimleri ile demokratik tutumları arasındaki ilişkinin incelenmesi (Yayınlanmamış yüksek lisans tezi). Marmara Üniversitesi Eğitim Bilimleri Enstitüsü, İstanbul.

Warden, B. J. (2004). Self-evaluation of reflective thinking among pre-service and in-service teachers (Unpublished doctoral thesis). Oklahoma State University.

Yıldırım, Ö. (2019). Sinıf öğretmeni adaylarının yansıtıcı düşünme eğilimleri ve öğrenme ögretme anlayışlarının incelenmesi (Yayınlanmamış yüksek lisans tezi). Manisa Celal Bayar Üniversitesi Sosyal Bilimler Enstitüsü, Manisa. 
Yıldız, Z. (2013). Illkögretim din kültürü ve ahlak bilgisi öğretmenlerinin yansitıcı düşünme eğilimlerinin değerlendirilmesi (Göller Yöresi Örneği) (Yayınlanmamış doktora tezi). Süleyman Demirel Üniversitesi Sosyal Bilimler Enstitüsü, Isparta.

Yılmaz, B. (2006). Beşinci sınıf ögretmenlerinin fen ve teknoloji dersinde yapılandırmacı ögrenme ortamı düzenleme becerileri (Yayınlanmamış yüksek lisans tezi). Yıldız Teknik Üniversitesi Sosyal Bilimler Enstitüsü, İstanbul.

Yumuşak, G. K. (2017). Yansıtıcı düşünmeye dayalı etkinliklerin bilimsel süreç becerilerinin gelişimine etkisi. Necatibey Eğitim Fakültesi Elektronik Fen ve Matematik Eğitimi Dergisi, 11(1), 222-251.

\section{EXTENDED ABSTRACT}

\section{Introduction}

Reflective thinking, which is accepted as an important driving force for the professional development of mathematics teachers, plays a major role in the realization of mathematics education goals, in producing solutions to the problems faced by mathematics teaching, and in evaluating their experiences in mathematics classrooms. Therefore, reflective thinking should be considered as an important part of teacher education and training programs (Aldahmash et al., 2021).

Many definitions are made in the literature regarding reflective thinking. It can also be said that the foundations of the concept of reflective thinking are very old (Gürbüz \& Bozan, 2018). When it comes to the basis of the study, it is seen that the first definitions of reflective thinking were made by Dewey (1993), and then there were many studies on it (Köksal \& Demirel, 2008, Ocak et al., 2013, Soft, 2015, Deringöl, 2019: 619). In later research processes, different perspectives were presented to reflective thinking by developing this definition. Reflective thinking, expressed in the literature, is expressed as a way of thinking about identifying positive and negative situations and solving the problems identified as a result of this identification (Sayg1lı \& Atahan, 2014). The concept of reflective thinking includes the concept of reflection within itself. The concept of reflection emerges as a concept that is also used in daily life (Bauer, 1991: 3). For this reason, the concept of reflection should also be defined briefly. Reflection is the ability of a person to express his / her ideas about a subject and to show their attitudes and skills about it (Duban \& Yelken, 2010).

According to the idea put forward by Mezirow (1991), the content of reflective thinking constitutes criticism towards the problem-solving stage or assumptions about the content. Again, according to the same opinion, criticism of the foundations and assumptions is primarily about presenting the problems, and a difference occurs in the solution of the problem. According to Mezirow, non-reflective behaviors have three characteristics. It is possible to distinguish between reflective and non-reflective behaviors by evaluating these indicators. These can be regarded as actions that have turned into a habit, actions that can be carried out without thinking, and actions that center themselves.

How important the concept of thinking is for human existence has been stated above. Although it is known in this way, there are not many branches related to direct thinking in the field of education. On the other hand, the idea of thinking and transferring thinking in terms of both educators and students underlies the education system. In fact, this philosophy is based on all other educational sciences (Deringöl, 2019: 619). People have come together to meet their various needs since their existence. Education is also an important need for humanity from past to present. States aim to establish qualified education systems to meet this need (Güzel et al., 
2010). The concept of quality education is also debated both in Turkey and in the world over the years. Increasing the quality of the teachers in Turkey has always been one of the major subjects (Aydin \& Steel, 2013). What is expected from teachers and pre-service teachers has always been to improve themselves, to be aware of their responsibilities, and to question themselves (Gözel \& Toptaş, 2017). The impact of the students educated by qualified teachers on both the society and the next generations is indisputable.

In the constructivist education system, it is expected that reflective thinking skills are acquired as a prerequisite for the competence of teachers and pre-service teachers (Ocak et al., 2013). The concepts of reflective thinking and constructivist approach are essentially two concepts that complement each other. When we look at from another point of view, we can see the presence of reflective thinking skills as a result of a critical perspective in the context of the constructivist approach (Lale, 2016). The expected results in the education system in the constructivist approachare the student's elimination of conventional and stereotyped teaching models. In this respect, in the constructivist approach, the student provides more active participation in the learning process and reveals the underlying thought instead of memorizing the concepts learned. Reflective thinking skill is also a skill that must be possessed in order to achieve the desired results in the constructivist education model of the student. In order to achieve this skill, openended questions that force people to think should be used (Y1ldirım, 2019). As mentioned in the content of the study, reflective thinking also affects the critical thinking skills of the student. In this way, the student can question the stereotyped teaching models and apply the knowledge they have learned instead of memorizing them.

In order to transfer the reflective thinking skill to the students, the educator must first have this skill (Varol \& Şanl1, 2016). At this point, the education system built on constructivist approach theories comes to the fore. Reflective thought-action also enables the person to restructure his own thinking system (Varol \& Şanl, 2016). For teachers, reviewing and restructuring one's own cognitive process is beneficial in transferring reflective thinking to students.

Reflective thinking makes the educational process enjoyable for the student as a result of structuring the students' knowledge (Temel, 2017). As a result, the memorized information is replaced by the learned information, and this becomes permanent for life. As of 2005, the constructivist approach has been taken as a basis in our education system. In the content of this approach, it is one of the points aimed at providing students and educators with reflective thinking skills (Erdoğan, 2019). At the foundation and goal of the constructivist model, the skill that should be acquired reflective thinking, or in other words, the skill that should be at the base of the education process, is the reflective thinking skill (Ülker, 2019).

\section{Purpose}

In the literature, there are no studies examining the relationship between secondary school mathematics teachers' reflective thinking tendencies and their constructivist learning environment. For this reason, the starting point of the study is to determine the relationship between the reflective thinking tendencies of middle school mathematics teachers and their constructivist learning environment. The aim of the study is to determine the relationship between secondary school mathematics teachers' reflective thinking tendencies and their constructivist learning environment.

\section{Method}

The research, conducted with a descriptive approach, was carried out using the relational screening model. The research population consists of middle school mathematics teachers working in Düzce, Karabük, Çorum and Kastamonu provinces. The 4 provinces specified in 
order to ensure the applicability of the researcher personally constitute the research universe. The research sample consists of 442 middle school mathematics teachers who were selected among 852 teachers in the universe with the appropriate sampling technique from non-random sampling methods. Personal Information Form, Reflective Thinking Tendency Scale, and Constructivist Learning Environment Formation Scale were used as data collection tools in the study. Frequency, arithmetic mean, and standard deviation techniques were used in the analysis of the data to determine the reflective thinking tendency and constructivist learning environment levels of the participants. As the data showed normal distribution, independent groups t-test and one-way ANOVA test were used to determine whether the variables in the sub-problems of the study made a difference. Post-Hoch, multiple comparison tests, was used to determine the source of difference between groups in the ANOVA test. Scheffe test was applied here due to the large difference between groups. Pearson correlation analysis was conducted to test the relationship between teachers' reflective thinking tendencies and their constructivist learning environment. Multiple linear regression analysis was conducted to test the predictive power of the tendencies of continuous and purposeful thinking, open-mindedness, questioning, and effective teaching responsibility, and being scientific, investigative, and predictive and sincere on constructivist learning environment levels.

\section{Findings and Interpretation}

According to the findings obtained from the analysis results, it is seen that teachers have a very high level of reflective thinking tendency. According to the total score of the scale, no significant difference was found in the reflective thinking tendencies of the teachers according to the variables of gender and in-service training. According to the variable of seniority, significant differences were found in favor of teachers with more seniority. Significant differences were found in teachers' reflective thinking tendencies in favor of teachers who willingly choose their profession and who are satisfied with their profession. It is seen that teachers' levels of constructing a constructivist learning environment are high. According to the total score of the scale, no significant difference was found in the teachers' levels of constructing a constructivist learning environment according to the variables of gender and seniority. However, there are significant differences in favor of teachers who willingly choose their profession and are satisfied with their profession. On the other hand, according to the result of the correlation between the sub-dimensions of the scales, it was found that there are generally moderate and positive significant relationships.

\section{Discussion and Conclusion}

It is concluded that teachers' reflective thinking tendencies are at a very high level. This result is consistent with the results obtained by Aslan (2009) and Üstün (2011). It was concluded that there was no significant difference in the reflective thinking tendency levels of secondary school mathematics teachers according to gender and in-service training variables. It has resulted that there are significant differences in favor of teachers with more professional experience according to the seniority variable; It has been concluded that teachers have high levels of the constructivist learning environment. This result is similar to the results obtained by Yilmaz (2006) and Iş1k (2014). However, the result of the study does not comply with the study results of Battal (2008) and Fidan (2010). It was concluded that there was no significant difference according to the gender and seniority variables. It was concluded that there is a moderately positive and significant relationship between secondary school mathematics teachers' reflective thinking tendencies and their constructivist learning environment. This result is consistent with the study results obtained by Aykar (2012) and Tunç (2019). In addition, it was concluded that 
teachers' reflective thinking tendency levels explained $37 \%$ of their level of the constructivist learning environment.

\section{Etik Kurul İzin:}

Yapılan bu çalışmada "Yükseköğretim Kurumları Bilimsel Araştırma ve Yayın Etiği Yönergesi” kapsamında uyulması belirtilen tüm kurallara uyulmuştur. Bu çalışma için etik kurul izni Düzce Üniversitesi Bilimsel Araştırma ve Yayın Etik Kurulu'nun 20/06/2019 tarihli ve 2019/58 numaralı kararı ile alınmıştır. 